\title{
GUIDELINES
}

\section{Guidelines to aid healing of acute wounds by decreasing impediments of healing}

\author{
Michael G. Franz, MD ${ }^{1,2}$; Martin C. Robson, MD ${ }^{1,3}$; David L. Steed, MD ${ }^{1,4}$; Adrian Barbul, MD ${ }^{5}$; Harold Brem, \\ $\mathrm{MD}^{10,11}$; Thomas L. Wachtel, MD, MMM, CPE ${ }^{12}$; Laurel Wiersema-Bryant, APN, BC ${ }^{13}$ \\ 1. Co-chaired this panel, \\ 2. Department of Surgery, University of Michigan, Ann Arbor, Michigan, \\ 3. Department of Surgery, University of South Florida, Tampa, Florida, \\ 4. Department of Surgery, University of Pittsburgh, Pittsburgh, Pennsylvania, \\ 5. Department of Surgery, Sinai Hospital/Johns Hopkins University, Baltimore, Maryland, \\ 6. Department of Surgery, NYU School of Medicine, New York, New York, \\ 7. PolyRemedy Inc., Mountain View, California, \\ 8. Department of Wound Healing, Cardiff University, Cardiff, Wales, United Kingdom, \\ 9. Department of Surgery, Johns Hopkins University, Baltimore, Maryland, \\ 10. Institute for Tissue Regeneration, Repair, and Rehabilitation, Bay Pines VA Healthcare System, Bay Pines, Florida, \\ 11. Division of Plastic Surgery, University of South Florida, Tampa, Florida, \\ 12. Department of Surgery, University of Arizona, Tucson, Arizona, and \\ 13. Barnes Jewish Hospital, Washington University, St. Louis, Missouri
} $\mathrm{MD}^{6}$; Diane M. Cooper, PhD, RN ; David Leaper, MD, $\mathrm{ChM}^{8}$; Stephen M. Milner, MBBS, BDS ${ }^{9}$; Wyatt G. Payne,

Achieving uniformity in the care rendered to patients with wounds has been a major desire of clinicians, government regulators, and third-party payers. ${ }^{1}$ One of the goals of the founders of the Wound Healing Society (WHS) in 1991 was to establish guidelines for wound treatment. One of the first tasks of the WHS Board of Directors following the first annual meeting in Galveston, TX, was to appoint a committee to develop treatment guidelines. ${ }^{1}$ This committee, under the direction of Gerald S. Lazarus, MD, realized that uniform care guidelines could not be developed because there was no uniformity in the definitions of wounds, wound healing, or wound attributes. The committee developed the necessary definitions and after several public hearings, the article "Definitions and guidelines for assessment of wounds and evaluation of healing" was published in $1994 .^{2}$

That publication defined an acute wound as one that proceeds through an orderly and timely reparative process to establish sustained anatomic and functional integrity, and defined a chronic wound as one that has failed to proceed through an orderly and timely reparative process to produce anatomic and functional integrity or has proceeded through the repair process without establishing a sustained anatomic and functional result. ${ }^{2}$ Simply stated, wounds may be classified as those that can repair themselves or can be repaired in an orderly and timely process (acute wounds) and those that cannot (chronic wounds).

In 2006, the WHS published "Guidelines for the best care of chronic wounds." 1 The chronic wounds chosen for treatment guideline development were venous, diabetic, arterial, and pressure ulcers. Because chronic wounds have impaired healing, evidence-based guidelines were developed to maximize healing trajectories and accelerate healing where possible. However, acute wounds are much more numerous than chronic wounds. There are $50,000,000$ elective surgical incisions made each year in the United States, and another 50,000,000 traumatic wounds. ${ }^{3}$ Add to this 1 million burn injuries and the scope of the problem becomes clear. As opposed to the chronic wound, healing in the acute wound is taken for granted. ${ }^{4}$ It is assumed that if one debrides a wound of nonviable tissue and repairs it in a physiologic manner, the normal phases of wound healing - reaction, regeneration, remodelingshould proceed without difficulty. $3,4,5$

Acute wounds are expected to heal with a "normal" wound healing trajectory" ${ }^{3}$ hence, accelerating healing has not been the goal in their treatment. Rather, the goal has been to remove detriments or deterrents to normal healing and eliminate the complications that may prevent an orderly and timely reparative process that could convert the acute wound into a chronic wound.

A panel was appointed to develop guidelines to "aid healing of acute wounds by decreasing impediments to healing." The panel consisted of general, vascular, plastic, trauma, burn, and cancer surgeons, nurse clinicians, and researchers drawn from academic, governmental, private practice, and industrial settings. These panel members represented most scientific, medical, and nursing societies/associations that have wound care as a major scope of interest. The panel limited the scope of acute wound healing to integument and soft tissue, and did not address bone, cartilage, neural tissue, or internal organs.

\section{REFERENCES}

1. Robson MC, Barbul A. Guidelines for the best care of chronic wounds. Wound Rep Regen 2006; 14: 647-8.

2. Lazarus GS, Cooper DM, Knighton DR, Margolis DJ, Pecoraro RE, Rodeheaver G, Robson MC. Definitions and guidelines for the assessment of wounds and evaluation of healing. Arch Dermatol 1997; 130: 489-93.

3. Franz MG, Steed DL, Robson MC. Optimizing healing of the acute wound by minimizing complications. Curr Prob Surg 2007; 44: 679-766. 
4. Robson MC. Wound infection: a failure of wound healing caused by an imbalance of bacteria. Surg Clin North Am 1997; 77: 637-50.

5. Robson MC. Disturbances in wound healing. Ann Emerg Med 1988; 17: 1274-8.

\section{METHODS}

Previous guidelines, meta-analyses, PubMed, MEDLINE, EMBASE, The Cochrane Database of Systematic Reviews, recent review articles of management of acute wounds and their complications were all searched and reviewed for evidence. Guidelines were formulated, the underlying principle(s) enumerated, and evidence references listed and coded. The code abbreviations for the evidence citations are as follows:

$\begin{array}{ll}\text { STAT } & \begin{array}{l}\text { Statistical analysis, meta-analysis, consensus } \\ \text { statement by commissioned panel of experts }\end{array} \\ \text { RCT } & \text { Randomized clinical trial } \\ \text { LIT REV } & \text { Literature review } \\ \text { CLIN S } & \text { Clinical case series } \\ \text { RETRO S } & \text { Retrospective series review } \\ \text { EXP } & \text { Laboratory or animal study } \\ \text { TECH } & \text { Technique or methodology description } \\ \text { PATHS } & \text { Pathological series review }\end{array}$

The approach used for evidence citations was the same as for the chronic wound guidelines. Major differences exist between this approach to evidence citations compared with past approaches to evidence-based guidelines. Most past approaches relied only on publications regarding clinical human studies. Laboratory or animal studies were not cited. The approach used here and in the previously published guidelines for treatment of chronic wounds used well-controlled animal studies that present proof of principle, especially when a clinical series corroborated the laboratory results. Because of these variations, a different system was used to grade the evidence weight supporting a given guideline. The level strength of evidence supporting a guideline is listed as Level I, Level II, or Level III. The guideline criteria for the levels are:

- Level I: Meta-analysis of multiple RCTs or at least two RCTs support the intervention of the guideline. Another route would be multiple laboratory or animal experiments with at least two clinical series supporting the laboratory results.

- Level II: Less than Level I, but at least one RCT and at least two significant clinical series or expert opinion papers with literature analysis, RCT, or multiple clinical series.

- Level III: Suggestive data of proof of principle, but lacking sufficient data such as meta-analysis, RCT, or multiple clinical series.

- NB: The suggestion in the guideline can be positive or negative at the proposed level (e.g., meta-analysis and two RCTs stating intervention is not an aid for decreasing impediments to healing).

\section{RESULTS}

Guidelines have been formulated in 11 categories of impediments to acute wound healing reported to lead to significant complications to normal tissue repair. The categories have been separated into five impediments that are local to the wound environment and six that are systemic conditions affecting the healing of acute wounds. These categories are:

Local:

- Wound perfusion

- Tissue viability

- Hematoma and/or seroma

- Infection

- Mechanical factors

Systemic:

- Immunology

- Oncology

- Miscellaneous systemic conditions

- Thermal injuries

- External agents

- Excessive scarring

Each of the guidelines underwent a DELPHI consensus among the panel members. Each set was critically evaluated by all panel members. There was a consensus of at least 10 of 11 panel members on each individual guideline. The majority of the guidelines had unanimous concurrence. The resultant draft, "Guidelines to aid healing of acute wounds by decreasing impediments to healing," was then reviewed by the WHS Board of Directors and posted on its website for public review and comment. All comments received by these two review processes were evaluated and modifications were made in the final document. The final document is presented as follows:

- \#1: Guidelines to decrease the impediment to acute wound healing caused by inadequate wound perfusion

- \#2: Guidelines to decrease the impediment to acute wound healing caused by nonviable tissue

- \#3: Guidelines to decrease the impediment to acute wound healing caused by wound hematoma or seroma

- \#4: Guidelines to decrease the impediment to acute wound healing caused by infection or an increased tissue bioburden

- \#5: Guidelines to decrease the impediment to acute wound healing caused by mechanical factors during wound repair

- \#6: Guidelines to decrease the impediment to acute wound healing caused by systemic immune deficiencies

- \#7: Guidelines to decrease the impediment to acute wound healing caused by cancer and its treatment

- \#8: Guidelines to decrease the impediment to acute wound healing caused by systemic conditions such as diabetes mellitus, obesity, malnutrition, etc

- \#9: Guidelines to decrease the impediment to acute wound healing caused by burn injuries

- \#10: Guidelines to decrease the impediment to acute wound healing caused by external agents such as tobacco, drugs, etc. 
- \#11: Guidelines to decrease the impediment to acute wound healing caused by excessive scar formation

\section{\# 1: GUIDELINES TO DECREASE THE IMPEDIMENT TO ACUTE WOUND HEALING CAUSED BY INADEQUATE WOUND PERFUSION}

Preamble: Adequate blood supply is a sine qua non to normal wound healing and tissue repair. Inadequate wound perfusion can occur from systemic causes, regional causes, and local causes.

Guideline \#1.1: Clinically significant arterial disease should be ruled out, preferably before wounding. In the lower extremity, this can be done by establishing that pedal pulses are clearly palpable or that the ankle-brachial index $(\mathrm{ABI})$ is $>0.9$. An $\mathrm{ABI}>1.3$ suggests noncompressible arteries. In elderly patients or patients with an ABI > 1.2, a normal Doppler-derived wave form, a toebrachial index of $>0.7$ or a transcutaneous oxygen pressure of $>40 \mathrm{mmHg}$ may help to suggest adequate arterial flow. Color duplex ultrasound scanning provides anatomic and physiologic data confirming an ischemic etiology for the leg wound.

Level of evidence: I

Principle: Ischemia hinders healing and increases the risk of infection. Although clinical history and physical examination can be very suggestive of ischemia, a definitive diagnosis must be established before undertaking a course of treatment. Successful healing requires that arterial insufficiency be addressed.

\section{Evidence:}

1. Hirsch A, Haskal ZJ, Hertzer NR, Bakal CW, Creager MA, Halperin JL, Hiratzka LF, Murphy WRC, Olin JW, Puschett JB, Rosenfield KA, Sacks D, Stanley JC, Taylor LM, White CJ, White J, White RA, Antman EM, Smith SC, Adams CD, Anderson JL, Faxon DP, Fuster V, Gibbons RJ, Halperin JL, Hiratzka LF, Hunt SA, Jacobs AK, Nishimura R, Ornato JP, Page RL, Riegel B. ACC/AHA Guidelines for the Management of Patients with Peripheral Arterial Disease (Lower Extremity, Renal, Mesenteric, and Abdominal Aortic): A Collaborative Report from the American Association for Vascular Surgery/Society for Vascular Surgery, Society for Cardiovascular Angiography and Interventions, Society of Interventional Radiology, Society for Vascular Medicine and Biology, and the American College of Cardiology/American Heart Association Task Force on Practice Guidelines (Writing Committee to Develop Guidelines for the Management of Patients With Peripheral Arterial Disease). American College of Cardiology Web Site. Available at: http://www.acc.org/clinical/ guidelines/pad/index.pdf. (STAT)

2. Sahli D, Eliasson B, Svensson M, Blohmé G, Eliasson M, Samuelsson P, Ojbrandt K, Eriksson JW. Assessment of toe blood pressure is an effective screening method to identify diabetes patients with lower extremity arterial disease. Angiology 2004; 55: 641-51. (CLIN S)
3. Teodorescu V, Chen C, Morrissey N, Faries PL, Marin ML, Hollier LH. Detailed protocol of ischemia and the use of noninvasive vascular laboratory testing in diabetic foot ulcers. Am J Surg 2004; 187: 75S-80S. (LIT REV)

4. Hirsch A, Criqui M, Treat-Jacobson D, Regensteiner JG, Creager MA, Olin JW, Krook SH, Hunninghake DB, Comerota AJ, Walsh ME, McDermott MM, Hiatt WR. Peripheral arterial disease detection, awareness, and treatment in primary care. $J A M A$ 2001; 286: 1317-24. (CLIN S)

5. Ascher E, Hingorani A, Markevich N, Yorkovich W, Schutzer R, Hou A, Jacob T, Nahata S, Kallakuri S. Role of duplex arteriography as the sole preoperative imaging modality prior to lower extremity revascularization surgery in diabetic and renal patients. Ann Vasc Surg 2004; 8: 433-9. (CLIN S)

6. Padberg FT, Back TL, Thompson PN, Hobson RW. Transcutaneous oxygen $\left(\mathrm{TcPO}_{2}\right)$ estimates probability of healing in the ischemic extremity. J Surg Res 1996; 60: 365-9. (CLIN S)

7. Butler CM, Ham RO, Lafferty K, Cotton LT, Roberts VC. The effect of adjuvant oxygen therapy on transcutaneous $\mathrm{pO}_{2}$ and healing in the below-knee amputee. Prosthet Orthot Int 1987; 11: 10-6. (RCT)

8. Bercelli SA, Chan AK, Pomposelli FB Jr, Gibbons GW, Campbell DR, Akbari CM, Brophy DT, LoGerfo FW. Efficacy of dorsal pedal artery bypass in limb salvage for ischemic heel ulcer. J Vasc Surg 1999; 30: 499-508. (RETRO S)

9. Lopantalo M, Biancari F, Tukiainen E. Never amputate without consultation of a vascular surgeon. Diabetes Metab Res Rev 2000; 16 (Suppl. 1): S27-32. (LIT REV)

10. Attinger CE, Ducic I, Neville RF, Abbruzzese MR, Gomes M, Sidawy AN. The relative roles of aggressive wound care versus revascularization in salvage of the threatened lower extremity in the renal failure diabetic patient. Plast Reconstr Surg 2002; 109: 1281-90. (CLIN S)

11. Moosa HH, Makaroun MS, Peitzman AB, Steed DL, Webster MW. $\mathrm{TcPO}_{2}$ values in limb ischemia: effects of blood flow and arterial oxygen tension. J Surg Res 1986; 40: 482-7. (EXP)

Guideline \#1.2: Hypotension and skin hypoperfusion should be corrected as soon as possible to improve cutaneous wound healing.

Level of evidence: I

Principle: Skin blood flow is reduced in multiple medical conditions, including shock and hypotension, hypovolemia, cold, connective tissue disease, arterial and venous impairment, advanced age, pain, smoking, diabetes mellitus, and cold. Conversely, warming can increase perfusion.

Evidence:

1. Kumar S, Wong PF, Melling AC, Leaper DJ. Effects of perioperative hypothermia and warming in surgical practice. Int Wound J 2005; 2: 193-204. (STAT)

2. Worthley LI. Shock: a review of pathophysiology and management. Part I. Crit Care Resusc 2000; 2: 55-65. (LIT REV) 
3. Saucy F, Dischl B, Delachaux A, Feihl F, Liaudet L, Waeber B, Corpataux JM. Foot skin blood flow following infrainguinal revascularization for critical lower limb ischemia. Eur J Vasc Endovasc Surg 2006; 31: 401-6. (CLIN S)

4. Kamler M, Goedeke J, Pizanis N, Milekhin V, Schade FU, Jakob H. In vivo effects of hypothermia on the microcirculation during extracorporeal circulation. Eur J Cardiothorac Surg 2005; 28: 259-65. (EXP)

5. Kanetaka T, Komiyama T, Onozuka A, Miyata T, Shigematsu H. Laser Doppler skin perfusion pressure in the assessment of Raynaud's phenomenon. Eur $J$ Vasc Endovasc Surg 2004; 27: 414-6. (RCT)

6. Kenney WI, Munce TA. Invited review: aging and human temperature regulation. J Appl Physiol 2003; 95: 2598-603. (LIT REV)

7. Weiss M, Milman B, Rosen B, Eisenstein Z, Zimlichman R. Analysis of the diminished skin perfusion in elderly people by laser Doppler flowmetry. Age Ageing 1992; 21: 237-41. (EXP)

8. Black CE, Huang N, Neligan PC, Levine RH, Lipa JE, Lintlop S, Forrest CR, Pang CY. Effect of nicotine on vasoconstrictor and vasodilator responses in human skin vasculature. Am J Physiol Regul Integr Comp Physiol 2001; 281: R1097-104. (EXP)

9. Williams DT, Price P, Harding KG. The influence of diabetes and lower limb arterial disease on cutaneous foot perfusion. J Vasc Surg 2006; 44: 770-5. (RCT)

10. Ngo BT, Hayes KD, DiMiao DJ, Srinivasan SK, Huerter CJ, Rendell MS. Manifestations of cutaneous diabetic microangiopathy. Am J Clin Dermatol 2005; 6: 225-37. (LIT REV)

11. Rendell M, Bamisedun O. Diabetic cutaneous microangiopathy. Am J Med 1992; 93: 611-8. (CLIN S)

12. Schubert V. Hypotension as a risk factor for the development of pressure sores in elderly subjects. Age Ageing 1991; 20: 255-61. (CLIN S)

13. LoGerfo FW, Coffman S. Vascular and microvascular disease in the foot in diabetes: implications for foot care. $N$ Engl J Med 1984; 311: 1615-9. (LIT REV)

14. Kurz A, Sessler DI, Lenhardt R. Perioperative normothermia to reduce the incidence of surgical-wound infection and shorten hospitalization. $N$ Engl $\mathrm{J} \mathrm{Med}$ 1996; 334: 1209-15. (RCT)

15. Melling AC, Baqar A, Scott EM, Leaper DJ. Effects of preoperative warming on the incidence of wound infection after clean surgery. Lancet 2001; 358: 876-80. (RCT)

Guideline \#1.3: There are not enough clinical data to recommend hyperbaric oxygen for improving healing of acute wounds.

\section{Level of evidence: II}

Principle: Although increased oxygen delivered at increased pressures could theoretically augment healing, there are insufficient data to support its use in acute wound healing.

\section{Evidence:}

1. Friedman HI, Fitzmaurice M, Lefaivre JF, Vecchiolla T, Clarke D. An evidence-based appraisal of the use of hyperbaric oxygen on flaps and grafts. Plast Reconstr Surg 2006; 117 (Suppl.): 175S-92S. (STAT)
2. Kaelin CM, Im MJ, Myers RA, Manson PN, Hoopes JE. The effects of hyperbaric oxygen on free flaps in rats. Arch Surg 1990; 125: 607-9. (EXP)

3. Tai YJ, Birely BC, Im MJ, Hoopes JE, Manson PN. The use of hyperbaric oxygen for preservation of free flaps. Ann Plast Surg 1992; 28: 284-7. (EXP)

4. Garcia-Covarrubias L, McSwain NE, Van Meter K, Bell RM. Adjuvant hyperbaric oxygen therapy in the management of crush injury and traumatic ischemia: an evidence-based approach. Am Surg 2005; 71: 144 51. (STAT)

5. Reedy MB, Capen CV, Baker DP, Petersen WG, Kuehl TJ. Hyperbaric oxygen therapy following radical vulvectomy: an adjunctive therapy to improve wound healing. Gynecol Oncol 1994; 53: 13-6. (CLIN S)

6. Sheffield P. Tissue oxygen measurements with respect to soft tissue wound healing with normobaric and hyperbaric oxygen. HBO Rev 1985; 6: 18-46. (LIT REV)

7. Bouachour G, Cronier P, Gouello JP, Toulemonde JL, Talha A, Alquier P. Hyperbaric oxygen therapy in the management of crush injuries: a randomized double-blind placebo-controlled trial. J Trauma 1996; 41: 333-9. (RCT)

\section{\# 2: GUIDELINES TO DECREASE THE IMPEDIMENT TO ACUTE WOUND HEALING CAUSED BY NONVIABLE TISSUE}

Preamble: None of the processes of wound healing can occur unless the tissues within the wound are viable. Attempting to close a wound by edge coaptation, with a skin graft, with a pedicled flap, or even allowing it to heal spontaneously, will be unsuccessful when nonviable tissue is present. Removing nonviable tissue is paramount to successful tissue repair.

Guideline \#2.1: Debridement is required to remove necrotic tissue and excessive bacterial burden. The health care provider can choose from a number of debridement methods, including surgical, enzymatic, mechanical, biological, or autolytic. More than one debridement method may be appropriate. (Sharp surgical debridement is preferred.)

If an alternative form of debridement is unsuccessful in removing the nonviable tissue, surgical debridement is mandated.

\section{Level of evidence: I}

Principle: Necrotic tissue, excessive bacterial burden, and foreign debris can all inhibit wound healing. The method of debridement chosen may depend on the status of the wound, the capability of the health care provider, the overall condition of the patient, and professional licensing restrictions.

Evidence:

1. Steed DL, Donohoe D, Webster MW, Lindsley L. Effect of extensive debridement on the healing of diabetic foot ulcers. J Am Coll Surg 1996; 183: 61-4. (RCT)

2. Saap LJ, Falanga V. Debridement performance index and its correlation with complete closure of diabetic foot ulcers. Wound Rep Regen 2002; 10: 354-9. (RCT) 
3. Mulder GD. Cost-effective managed care: gel versus wet-to-dry for debridement. Ostomy Wound Manage 1995; 41: 68-70. (RCT)

4. Alvarez OM, Fernandez-Obregon A, Rogers RS, Bergamo L, Masso J, Black M. A prospective, randomized, comparative study of collagenase and papain-urea for pressure ulcer debridement. Wounds 2002; 14: 293-301. (RCT)

5. Steed DL. Debridement. Am J Surg 2004; 187 (Suppl.): 71S-4S. (LIT REV)

6. Ayello EA, Cuddigan JE. Debridement: controlling the necrotic/cellular burden. Adv Skin Wound Care 2004; 17: 66-75. (LIT REV)

7. Sieggreen MY, Maklebust J. Debridement: choices and challenges. Adv Wound Care 1997; 10: 32-7. (LIT REV)

8. Sibbald RG, Williamson D, Orsted HL, Campbell K, Keast D, Krasner D, Sibbald D. Preparing the wound bed-debridement, bacterial balance, and moisture balance. Ostomy Wound Manage 2000; 46: 14-35. (LIT REV)

9. Mosher BA, Cuddigan J, Thomas DR, Boudreau DM. Outcomes of 4 methods of debridement using a decision analysis methodology. Adv Wound Care 1999; 12: 81-8. (TECH)

10. Bradley M, Cullum N, Sheldon T. The debridement of chronic wounds: a systematic review. Health Technol Assess 1999; 3 (Part 1): (STAT)

11. Alvarez OM, Mertz PM, Eaglstein WH. The effect of occlusive dressings on collagen synthesis and reepithelialization in superficial wounds. J Surg Res 1983; 35: 142-8. (EXP)

12. Falanga V. Wound bed preparation and the role of enzymes: a case for multiple actions of the therapeutic agents. Wounds 2002; 14: 47-57. (LIT REV)

13. Rao DB, Sane PG, Georgiev EL. Collagenase in the treatment of dermal and decubitus ulcers. J Am Geriatr Soc 1975; 23: 22-30. (CLIN S)

14. Capasso VA, Munro BH. The cost and efficacy of two wound treatments. AORN J 2003; 77: 984-1004. (RETRO S)

15. Piaggesi A, Schipani E, Campi F, Romanelli M, Baccetti F, Arvia C, Navalesi R. Conservative surgical approach versus non-surgical management for diabetic neurotrophic foot ulcers: a randomized trial. $D i$ abetic Med 1998; 15: 412-7. (RCT)

16. Jensen JL, Seeley J, Gillin B. Diabetic foot ulcerations. a controlled, randomized comparison of two moist wound healing protocols: Carrasyn Hydrogel Wound dressing and wet-to-moist saline gauze. Adv Wound Care 1998; 11 (Suppl. 7): 1-4. (RCT)

17. Hamer ML, Robson MC, Krizek TJ, Southwick WO. Quantitative bacterial analysis of comparative wound irrigations. Ann Surg 1975; 181: 819-22. (EXP)

18. Granick MS, Tenenhaus M, Knox R, Ulm JP. Comparison of wound irrigation and tangential hydrodissection in bacterial clearance of contaminated wounds: results of a randomized, controlled clinical study. $O s$ tomy Wound Manage 2007; 53: 64-66, 68-70, 72. (RCT)

19. Bhandari M, Thompson K, Adili A, Schaughnessy SG. High and low pressure irrigation in contaminated wounds with exposed bone. Int J Surg Investig 2000; 2 : 179-82. (EXP)
20. Draeger RW, Dahners LE. Traumatic wound debridement: a comparison of irrigation Methods 2006; 20: 83-8. (EXP)

21. Mumcuoglu KY. Clinical application of maggots in wound care. Am J Clin Dermatol 2001; 2: 219-27. (LIT REV)

\section{\# 3: GUIDELINES TO DECREASE THE IMPEDIMENT TO ACUTE WOUND HEALING CAUSED BY WOUND HEMATOMA OR SEROMA}

Preamble: Acute wound fluid collections most often are the result of bleeding (hematomas), inflammation (seromas), or lymph fluid. Acute wound hematomas or seromas can impair and delay acute wound healing. Acute wound fluid collections can mechanically disrupt a wound, cause wound ischemia due to pressure exceeding capillary perfusion, be a nutrient nidus for wound infection, or cause increased dead space. Wound hematomas are increasingly common due to the increased use of prophylactic and therapeutic anticoagulation and antiplatelet therapy in surgical patients. Wound seromas are increasingly common due to the increased use of foreign material soft tissue implants, such as meshes used in hernia repair.

Guideline \#3.1: Coagulation should preferentially be normalized preoperatively; correction should continue intraoperatively and for 24 hours following a surgical procedure. Primary coagulopathies such as vitamin K deficiency or hemophilia should be diagnosed and treated before elective operations. Therapeutic anticoagulation, as with warfarin, can be temporarily discontinued and "bridged" with shorter-acting anticoagulants. Prophylactic heparins to prevent venous thromboembolism (VTE) are indicated, but will increase the risk of hematomas and other bleeding complications. Antiplatelet agents may be continued during general surgical procedures.

Level of evidence: I

Principle: Bleeding complications, including hematoma formation, are significantly increased when a primary or pharmacological coagulopathy exists. The most common mechanism for coagulopathy is impaired or reduced protein-clotting factors and impaired or reduced platelets. Patients at high risk for a hypercoagulable complication such as stroke, myocardial ischemia, or VTE may be "bridged" with a heparin formulation that can be held during the 24hour period surrounding an operation. Heparin prophylaxis against VTE is indicated in general surgery, but will increase the incidence of hematoma and bleeding complications. There is no evidence that prophylactic or therapeutic antiplatelet therapy increases the risk of acute wound hematomas.

Evidence:

1. Geerts WH, Heit JA, Clagett GP, Pineo GF, Colwell CW, Anderson FA Jr, Wheeler HB. Prevention of venous thromboembolism. Chest 2001; 119 (Suppl.): 132S-75S. (STAT)

2. Bergqvist D, Lindgren B, Matzsch T. Comparison of the cost of preventing postoperative deep vein 
thrombosis with either unfractionated or low molecular weight heparin. Br J Surg 1996; 83: 1548-52. (RCT)

3. Wille-Jorgensen P, Rasmussen MS, Andersen BR, Borly L. Heparins and mechanical methods for thromboprophylaxis in colorectal surgery. Cochrane Colorectal Cancer Group. Cochrane Database Syst Rev 2007; 4. (STAT)

4. Best WR, Khuri SF, Phelan M, Hur K, Henderson WG, Demakis JG, Daley J. Identifying patient preoperative risk factors and postoperative adverse events in administrative databases: results from the Department of Veterans Affairs National Surgical Quality Improvement Program. J Am Coll Surg 2002; 194: 257-66. (STAT)

5. Dunne JR, Malone DL, Tracy K, Napolitano LM. Abdominal wall hernias: risk factors for infection and resource utilization. J Surg Res 2003; 111: 78-84. (STAT)

6. Cruse PJ, Foord R. A five-year prospective study of 23,649 surgical wounds. Arch Surg 1973; 107: 206-10. (STAT)

7. Sharma S, Chang DW, Koutz C. Incidence of hematoma associated with ketorolac after TRAM flap breast reconstruction. Plast Reconstr Surg 2001; 107: 353-5. (CLIN S)

8. Koch A, Bouges S, Ziegler S, Dinkel H, Daures JP, Victor N. Low molecular weight heparin and unfractionated heparin in thrombosis prophylaxis after major surgical intervention: update of previous metaanalyses. Br J Surg 1997; 84: 750-9. (STAT)

9. Ammann JF, Aebi B. Hemorrhage risk of thromboembolism prophylaxis in general surgery. Helv Chir Acta 1983; 50: 7-8. (LIT REV)

10. Ammann JF, Aebi B. The risk of hemorrhaging in the prevention of thromboembolism in general surgery. Chirurg 1983; 54: 29-32. (RCT)

11. Chlan LL, Sabo J, Savik K. Effects of three groin compression methods on patient discomfort, distress, and vascular complications following a percutaneous coronary intervention procedure. Nurs Res 2005; 54: 391-8. (RCT)

12. Dorffler-Melly J, Koopman MMW, Prins MH, Buller HR. Antiplatelet and anticoagulant drugs for prevention of restenosis/reocclusion following peripheral endovascular treatment. Cochrane Peripheral Vascular Diseases Group. Cochrane Database Syst Rev 2007; 4. (STAT)

13. Antiplatelet Trialists' Collaboration. Collaborative overview of randomised trials of antiplatelet therapyIII: reduction in venous thrombosis and pulmonary embolism by antiplatelet prophylaxis among surgical and medical patients. BMJ 1994; 308: 23546. (STAT)

14. Kargi E, Babuccu O, Hosnuter M, Babuccu B, Altinyazar C. Complications of minor cutaneous surgery in patients under anticoagulant treatment. Aesthetic Plast Surg 2002; 26: 483-5. (RCT)

15. Warkentin TE, Crowther MA. Reversing anticoagulants both old and new. Can J Anaesth 2002; 49: S115. (LIT REV)

16. Brophy MT, Flore LD, Deykin D. Low-dose vitamin $\mathrm{K}$ therapy in excessively anticoagulated patients: a dose-finding study. J Thromb Thrombolysis 1997; 4: 289-92. (CLIN S)

17. Spotnitz WD, Dalton MS, Baker JW, Nolan SP. Reduction of perioperative hemorrhage by anterior mediastinal spray application of fibrin glue during cardiac operations. Ann Thorac Surg 1987; 44: 52931. (RCT)

Guideline \#3.2: Meticulous surgical hemostasis by ligature or electrocautery reduces the incidence of wound hematoma formation and improves wound healing.

\section{Level of evidence: I}

Principle: Surgical hemostasis prevents hematoma formation. Larger bleeding vessels in a wound should be clamped and tied with an absorbable suture. Electrocautery is an option for wound hemostasis, as are topical chemical hemostatic agents. Primary layered anatomic closure of an incision results in most efficient hemostasis, wound healing, and an optimized anatomic result. By achieving complete hemostasis, hematoma formation is minimized and "dead space" is eliminated, reducing the added risk of localized bacteria utilizing the hematoma as a nutrient media.

\section{Evidence:}

1. Patterson ML, Nathanson SD, Havstad S. Hematomas following excisional breast biopsies for invasive breast carcinoma: the influence of deep suture approximation of breast parenchyma. Am Surg 1994; 60: 845-8. (CLIN S)

2. Brown SR, Goodfellow PB. Transverse versus midline incisions for abdominal surgery. Cochrane Colorectal Cancer Group. Cochrane Database Syst Rev 2007; 4. (STAT)

3. Rappaport WD, Hunter GC, Allen R, Lick S, Halldorsson A, Chvapil T, Holcomb M, Chvapil M. Effect of electrocautery on wound healing in midline laparotomy incisions. Am J Surg 1990; 160: 618-20. (CLIN S)

4. Cruse PJ, Foord R. The epidemiology of wound infection: a 10-year prospective study of 62,939 wounds. Surg Clin North Am 1980; 60: 27-40. (STAT)

5. Johnson CD, Serpell J. Wound infection after abdominal incision with scalpel or diathermy. Br J Surg 1990; 77: 626-7. (RCT)

6. Kearns SR, Connolly EM, McNally S, McNamara DA, Deasy J. Randomized clinical trial of diathermy versus scalpel incision in elective midline laparotomy. Br J Surg 2001; 88: 41-4. (RCT)

7. Kumagai SG, Rosales RF, Hunter GC, Rappaport WD, Witzke DB, Chvapil TA, Chvapil M, Sutherland JC. Effects of electrocautery on midline laparotomy wound infection. Am J Surg 1991; 162: 620-3. (CLIN S)

8. Lawrenson KB, Stephens FO. The use of electro-cutting and electro-coagulation in surgery. Austral NZ J Surg 1970; 39: 417-21. (LIT REV)

9. Keenan KM, Rodeheaver GT, Kenney JG, Edlich RF. Surgical cautery revisited. Am J Surg 1984; 147: 818-21. (LIT REV)

10. Groot G, Chappell EW. Electrocautery used to create incisions does not increase wound infection rates. $\mathrm{Am}$ J Surg 1994; 167: 601-3. (CLIN S) 
11. Naumann RW, Hauth JC, Owen J, Hodgkins PM, Lincoln T. Subcutaneous tissue approximation in relation to wound disruption after cesarean delivery in obese women. Obstet Gynecol 1995; 85: 412-6. (RCT)

12. Dubay DA, Franz MG. Acute wound healing: the biology of acute wound failure. Surg Clin North Am 2003; 83: 463-81. (LIT REV)

Guideline \#3.3: Primarily closed, large surface area wounds with skin flaps such as after mastectomy or abdominal wall component separation should be prophylactically drained. Primary incisions or incisions associated with vascular implants do not benefit from closed suction drainage.

Level of evidence: I

Principle: The necessary "dead-space" created during flap elevation or the resection of a lymph node chain, for example, may allow significant fluid collection. This fluid may collect to the point that capillary perfusion pressure to the surrounding tissue is exceeded, causing ischemia and even necrosis. Fluid collections also may mechanically disrupt healing tissue layers. Chronically, wound fluid collections are at risk for becoming infected and forming an abscess. All phases along this continuum delay wound healing.

\section{Evidence:}

1. de Vries Reilingh TS, van Goor H, Rosman C, Bemelmans MH, de Jong D, van Nieuwenhoven EJ, van Engeland MI, Bleichrodt RP. "Components separation technique" for the repair of large abdominal wall hernias. J Am Coll Surg 2003; 196: 32-7. (CLIN S)

2. DiBello JN, Moore JH. Sliding myofascial flap of the rectus abdominus muscles for the closure of recurrent ventral hernias. Plast Reconstr Surg 1996; 98: 464-9. (CLIN S)

3. Schumpelick V, Conze J, Klinge U. Preperitoneal mesh repair of incisional hernias: a comparative retrospective study. Chirurg 1996; 67: 1028-35. (RETRO S)

4. Sugarman HJ. Surgery for morbid obesity. Surgery 1993; 114: 865-7. (LIT REV)

5. Pogson CJ, Adwani A, Ebbs SR. Seroma following breast cancer surgery. Eur J Surg Onc 2003; 29: 711-7. (CLIN S)

6. Cameron AE, Ebbs SR, Wylie F. Suction drainage of the axilla: a prospective randomized trial. $\mathrm{Br} J$ Surg 1988; 75: 1211 (RCT)

7. Somers R, Jablon L, Kaplan M. The use of closed suction drainage after lumpectomy and axillary dissection for breast cancer: a prospective randomized trial. Ann Surg 1992; 215: 146-9. (RCT)

8. Schultz I, Barrholm M, Grondal S. Delayed shoulder exercises in reducing seroma frequency after modified radical mastectomy: a prospective, randomized trial. Ann Surg Onc 1997; 4: 292-7. (RCT)

9. Shaffer D, Benotti PN, Bothe A Jr, Jenkins RL, Blackburn GL. A prospective, randomized trial of abdominal wound drainage in gastric bypass surgery. Ann Surg 1987; 206: 134-7. (RCT)

10. Healy DA, Keyser J III, Holcomb GW III, Dean RH, Smith BM. Prophylactic closed suction drainage of femoral wounds in patients undergoing vascular reconstruction. J Vasc Surg 1989; 10: 166-8. (RCT)
11. Higson RH, Kettlewell MG. Parietal wound drainage in abdominal surgery. Br J Surg 1978; 65: 326-9. (CLIN S)

12. Fraser I, Everson NW, Nash JR. A randomised prospective trial of two drainage methods after cholecystectomy. Ann $R$ Coll Surg Engl 1982; 64: 183-5. (RCT)

Guideline \#3.4: Large postoperative hematomas or seromas with evidence of wound ischemia or infection should be therapeutically drained or evacuated.

\section{Level of evidence: I}

Principle: Wound hematomas or seromas may reach a pressure at which capillary perfusion pressure to the surrounding wound tissue is exceeded. The resulting wound ischemia may lead to acute wound failure or wound infection. Chronically, a wound hematoma may act as a nidus for a wound infection and abscess. Opening a surgical wound and evacuating the fluid or hematoma should correct both of these complications. In the patient who receives a minimally invasive surgical procedure where there are minimal skin incisions, such as following laparoscopic hernia repair, percutaneous aspiration may be attempted.

\section{Evidence:}

1. Irvin TT, Goligher JC. A controlled clinical trial of three different methods of perineal wound management following excision of the rectum. Br J Surg 1975; 62: 287-91. (RCT)

2. Byrne DJ, Lynch W, Napier A, Davey P, Malek M, Cuschieri A. Wound infection rates: the importance of definition and post-discharge wound surveillance. J Hosp Infect 1994; 26: 37-43. (RCT)

3. Purushotham AD, McLatchie E, Young D, George WD, Stallard S, Doughty J, Brown DC, Farish C, Walker A, Millar K, Murray G. Randomized clinical trial of no wound drains and early discharge in the treatment of women with breast cancer. Br J Surg 2002; 89: 286-92. (RCT)

4. Youssef F, Jenkins MP, Dawson KJ, Berger L, Myint $F$, Hamilton $G$. The value of suction wound drain after carotid and femoral artery surgery: a randomised trial using duplex assessment of the volume of post-operative haematoma. Eur J Vasc Endovasc Surg 2005; 29: 162-6. (RCT)

5. Rice DC, Morris SM, Sarr MG, Farnell MB, van Heerden JA, Grant CS, Rowland CM, Ilstrup DM, Donohue JH. Intraoperative topical tetracycline sclero-therapy following mastectomy: a prospective, randomized trial. J Surg Oncol 2000; 73: 224-7. (RCT)

6. Knight CD Jr, Griffen FD, Knight CD Sr. Prevention of seromas in mastectomy wounds. The effect of shoulder immobilization. Arch Surg 1995; 130: 99-101. (CLIN S)

7. DeMaria, EJ, Moss JM, Sugerman, HJ. Laparoscopic intraperitoneal polytetrafluoroethylene (PTFE) prosthetic patch repair of ventral hernia: prospective comparison to open prefascial polypropylene mesh repair. Surg Endosc 2000; 14: 326-9. (CLIN S) 


\section{\#4: GUIDELINES TO DECREASE THE IMPEDIMENTS TO ACUTE WOUND HEALING CAUSED BY INFECTION OR AN INCREASED TISSUE BACTERIAL BIOBURDEN}

Preamble: Infection results in a wound when the bacteriahost defense equilibrium is upset in favor of the bacteria. When an imbalance in this quantitative equilibrium results in infection, a delay in wound healing occurs. Therefore, prevention and treatment of wound infection involves maintenance or reestablishment of the balanced equilibrium.

Guideline \#4.1: Do not attempt to close wounds containing $>10^{5}$ bacteria/g of tissue or any tissue level of beta hemolytic streptococci by direct wound edge approximation, skin graft, or pedicled or free flap.

\section{Level of evidence: I}

Principle: "A wound containing contaminated foci with greater than $10^{5}$ bacteria per gram of tissue cannot be readily closed, as the incidence of wound infection that follows is 50 to 100 percent" (Tobin, 1984).

\section{Evidence:}

1. Edlich RF, Rodeheaver GT, Thacker JG, Winn HR, Edgerton MT. Management of soft tissue injury. Clin Plast Surg 1977; 4: 191-8. (LIT REV)

2. Robson MC, Duke WF, Krizek TJ. Rapid bacterial screening in the treatment of civilian wounds. J Surg Res 1973; 14: 426-30. (RCT)

3. Liedburg NC, Reiss E, Artz CP. The effect of bacteria on the take of split-thickness skin grafts in rabbits. Ann Surg 1955; 142: 92-6. (EXP)

4. Krizek TJ, Robson MC, Kho E. Bacterial growth and skin graft survival. Surg Forum 1967; 18: 518-9. (RCT)

5. Murphy RC, Robson MC, Heggers JP, Kadowaki M. The effect of microbial contamination on musculocutaneous and random flaps. J Surg Res 1986; 41: 75-80. (EXP)

6. Tobin GR. Closure of contaminated wounds: biologic and technical considerations. Surg Clin North Am 1984; 64: 639-52. (LIT REV)

7. Robson MC, Lea CE, Dalton JB, Heggers JP. Quantitative bacteriology and delayed wound closure. Surg Forum 1968; 19: 501-2. (RCT)

8. Robson MC, Stenberg BD, Heggers JP. Wound healing alterations caused by infection. Clin Plast Surg 1990; 17: 485-92. (LIT REV)

Guideline \#4.2: When wounds are considered at risk for having a significant bacterial bioburden (clean-contaminated or contaminated cases), prophylactic antibiotics are indicated. Clean cases with negligible bacterial bioburden do not benefit from prophylactic antibiotics except when implanted prosthetic materials are used.

\section{Level of evidence: I}

Principle: Clean-contaminated and contaminated wounds result in higher rates of postoperative infection. Clean-refined and clean cases have infection rates that are low enough to make it difficult to demonstrate statistical improvement with prophylactic antibiotic usage.

\section{Evidence:}

1. Bratzler DW, Houk PM. Antimicrobial prophylaxis for surgery: an advisory statement from the National Surgical Infection Prevention Project. Clin Infect Dis 2004; 38: 1706-15. (STAT)

2. Dellinger EP, Gross PA, Barrett TL, Krause PJ, Martone WJ, McGowan JE Jr., Sweet RL, Wenzel RP. Quality standard for antimicrobial prophylaxis in surgical procedures. Clin Infect Dis 1994; 18: 422-7. (STAT)

3. Page CP, Bohner JM, Fletcher JR, McManus AT, Solomkin JS, Wittmann DH. Antimicrobial prophylaxis for surgical wounds: guidelines for clinical care. Arch Surg 1993; 128: 79-88. (STAT)

4. Waddell TK, Rotstein OD. Antimicrobial prophylaxis in surgery: Committee on Antimicrobial Agents, Canadian Infectious Disease Society. Canad Med Assoc J 1994; 151: 925-31. (STAT)

5. Sanchez-Manuel FJ, Lozano-Garcia J, Seco-Gil JL. Antibiotic prophylaxis for hernia repair. Cochrane Database Syst Rev 2007; 3: CD003769. (STAT)

6. Sanabria A, Dominguez LC, Valdivieso E, Gomez G. Prophylactic antibiotics for mesh hernioplasty: a meta-analysis. Ann Surg 2007; 246: 904-5. (STAT)

7. Hauser CJ, Adams CA, Eachempati SR, Council of the Surgical Infection Society. Surgical Infection Society guideline: prophylactic antibiotic use in open fractures: an evidence-based guideline. Surg Infect 2006; 7: 379-405. (STAT)

8. Whittaker JP, Nancarrow JD, Sterne GD. The role of antibiotic prophylaxis in clean incised hand injuries: a prospective randomized placebo controlled double blind trial. J Hand Surg 2005; 30: 162-7. (RCT)

9. Cummings P, DelBeccaro MA. Antibiotics to prevent infection of simple wounds: a meta-analysis of randomized studies. Am J Emerg Med 1995; 13: 396 400. (STAT)

10. Platt R. Methodologic aspects of clinical studies of perioperative antibiotic prophylaxis. Rev Infect Dis 1991; 13 (Suppl. 10): S810-4. (LIT REV)

11. Leaper DJ, van Goor H, Reilly J, Petrosillo N, Geiss HK, Torres AJ, Berger A. Surgical site infection-a European perspective of incidence and economic burden. Int Wound J 2004; 1: 247-3. (STAT)

12. Mangram AJ, Horan TC, Pearson ML, Silver LC, Jarvis WR. Guideline for prevention of surgical site infection, 1999. Infect Control Hosp Epidemiol 1999; 20: 247-78. (STAT)

Guideline \#4.3: When prophylactic antibiotics are to be used, they must be started preoperatively so as to obtain an adequate serum and, preferably, a tissue antimicrobial level before incision or wounding.

Level of evidence: I

Principle: Antibiotics begun after bacterial tissue lodgment has occurred cannot favorably affect the bacterialhost defense balance.

\section{Evidence:}

1. Burke JF. The effective period of preventive antibiotic action in experimental incisions and dermal lesions. Surgery 1961; 50: 161-8. (EXP)

2. Classen DC, Evans RS, Pestotnik SL, Horn SD, Menlove RL, Burke JP. The timing of prophylactic 
administration of antibiotics and the risk of surgical infection. N Engl J Med 1992; 326: 281-6. (RCT)

3. Bratzler DW, Houk PM. Antimicrobial prophylaxis for surgery: an advisory statement from the National Surgical Infection Prevention Project. Clin Infect Dis 2004; 38: 1706-15. (STAT)

4. Dellinger EP, Gross PA, Barrett TL, Krause PJ, Martone WJ, McGowan JE Jr, Sweet RL, Wenzel RP. Quality standard for antimicrobial prophylaxis in surgical procedures. Clin Infect Dis 1994; 18: 422-7. (STAT)

5. Page CP, Bohnen JM, Fletcher JR, McManus AT, Solomkin JS, Wittmann DH. Antimicrobial prophylaxis for surgical wounds: guidelines for clinical care. Arch Surg 1993; 128: 79-88. (STAT)

6. Polk HC, Lopez-Mayor JF. Postoperative wound infection: a prospective study of determinant factors and prevention. Surgery 1969; 66: 97-103. (RCT)

7. Meakins JL. Surgical infections: diagnosis and treatment. New York: Scientific American, 1994. (LIT REV)

Guideline \#4.4: When prophylactic antibiotics are indicated, a single dose is often sufficient. If multiple doses are used, they should be confined to a 24-hour period and not of prolonged duration.

Level of evidence: I

Principle: A single dose of the proper antibiotic, delivered at the proper time, will usually be effective at maintaining or reestablishing the bacteria-host defense equilibrium.

\section{Evidence:}

1. MacDonald M, Grabsel E, Marshall C, Forbes A. Single- versus multiple-dose antimicrobial prophylaxis for major surgery: a systematic review. Aust NZ J Surg 1998; 68: 388-96. (STAT)

2. Bratzler DW, Houk PM. Antimicrobial prophylaxis for surgery: an advisory statement from the National Surgical Infection Prevention Project. Clin Infect Dis 2004; 38: 1706-15. (STAT)

3. Cornwell EE III, Dougherty WR, Berne TV, Velmahos G, Murray JA, Chahwan S, Belzberg H, Falabella A, Morales IR, Asensio J, Demetriades D. Duration of antibiotic prophylaxis in high risk patients with penetrating abdominal trauma: a prospective randomized trial. J Gastrointest Surg 1999; 3: 648-53. (RCT)

4. Mohri Y, Tonouchi H, Kobayashi M, Nakai K, Kusunoki M, Mie Surgical Infection Research Group. Randomized clinical trial of single- versus multipledose antimicrobial prophylaxis in gastric cancer surgery. Br J Surg 2007; 94: 683-9. (RCT)

5. Fugita S, Saito N, Yamada T, Takii Y, Kondo K, Ohue M, Ikeda E, Moriya Y. Randomized multicenter trial of antibiotic prophylaxis in elective colorectal surgery: single dose vs 3 doses of a second-generation cephalosporin without metronidazole and oral antibiotics. Arch Surg 2007; 142: 657-61. (RCT)

Guideline \#4.5: In minor superficial, nonbite injuries, prophylactic antibiotics are not indicated.

Level of evidence: I

Principle: Minor superficial lacerations rarely contain a significant bacterial bioburden and do not benefit from prophylactic antibiotics. Bite injuries from animals and humans usually have significant contamination.

\section{Evidence:}

1. Whittaker JP, Nancarrow JD, Sterne GD. The role of antibiotic prophylaxis in clean incised hand injuries: a prospective randomized placebo controlled double blind study. J Hand Surg 2005; 30: 162-7. (RCT)

2. Cassell OC, Ion L. Are antibiotics necessary in the surgical management of upper limb lacerations? Br J Plast Surg 1997; 50: 523-9. (RCT)

3. Cummings P. Antibiotics to prevent infection in patients with dogbite wounds: a meta-analysis of randomized trials. Ann Emerg Med 1994; 23: 577-9. (STAT)

4. Hendrick TL, Smith PW, Gazoni LM, Sawyer RG. The appropriate use of antibiotics in surgery: a review of surgical infection. Curr Prob Surg 2007; 44: 635-75. (LIT REV)

5. Robson MC, Duke WF, Krizek TJ. Rapid bacterial screening in the treatment of civilian wounds. J Surg Res 1973; 14: 426-30. (RCT)

Guideline \#4.6: Assuring adequate patient temperature and oxygenation during surgery and in the perioperative period decreases surgical site infections.

\section{Level of evidence: I}

Principle: Normothermia and absence of hypoxia increase tissue perfusion and aid healing as well as decreasing surgical site infections.

\section{Evidence:}

1. Melling AC, Ali B, Scott EM, Leaper DJ. Effects of preoperative warming on incidence of wound infection after clean surgery: a randomized controlled trial. Lancet 2001; 358: 876-80. (RCT)

2. Kurz A, Sessler DI, Lenhardt R. Perioperative normothermia to reduce the incidence of surgical-wound infection and shorten hospitalization. N Engl J Med 1996; 334: 1209-15. (RCT)

3. Ueno C, Hunt TK, Hopf HW. Using physiology to improve surgical wound outcomes. Plast Reconstr Surg 2006; 117 (Suppl.): 59S-71S. (LIT REV)

4. Greif R, Akça O, Horn EP, Kurz A, Sessler DI. Supplemental perioperative oxygen to reduce the incidence of surgical-wound infection. $N$ Engl J Med 2000; 342: 161-7. (RCT)

5. Belda FJ, Aguilera L, García de la Asunción J, Alberti J, Vicente R, Ferrándiz L, Rodríguez R, Company R, Sessler DI, Aguilar G, Botello SG, Ortí R, Spanish Reduccion de la Tasa de Infeccion Quirurgica Group. Supplemental perioperative oxygen and the risk of surgical wound infection. A randomized controlled trial. JAMA 2005; 294: 2035-42. (RCT)

6. Pryor KO, Fahey TJ, Lien CA, Goldstein PA. Surgical site infection and the routine use of perioperative hyperoxia in a general surgical population. A randomized controlled trial. JAMA 2004; 291: 79-87. (RCT)

7. Myles PS, Leslie K, Chan MTV, Forbes A, Paech MJ, Peyton P, Silbert BS, Pascoe E, ENIGMA Trial Group. Avoidance of nitrous oxide for patients undergoing major surgery. Anesthesiology 2007; 107: 221-31. (RCT) 
Guideline \#4.7: Preoperative surgical site or wound preparation such as shaving of hair or scrubbing of the skin is not indicated as a means of decreasing incisional wound infection.

Level of evidence: I

Principle: The known resident bacterial flora of skin is $10^{3}$ bacteria/g of tissue, less than the bioburden required to cause infection.

\section{Evidence:}

1. Niel-Weise BS, Willie JC, van den Broek PJ. Hair removal policies in clean surgery: a systematic review of randomized, controlled trials. Inf Control Hosp Epidemiol 2005; 26: 923-8. (STAT)

2. Tanner J, Woodings D, Moncaster K. Preoperative hair removal to reduce surgical site infection. Cochrane Database Syst Rev 2006; 3: CD004122. (STAT)

3. Webster J, Osbourne S. Meta-analysis of preoperative antiseptic bathing in prevention of surgical site infection. Br J Surg 2006; 11: 13335-41. (STAT)

4. Ellenhorn JD, Smith DD, Schwarz RE, Kawachi MH, Wilson TG, McGonigle KF, Wagman LD, Paz IB. Paint-only is equivalent to scrub-and-paint in preoperative preparation of abdominal surgery sites. J Am Coll Surg 2005; 201: 737-41. (RCT)

5. Edwards PS, Lipp A, Holmes A. Preoperative skin antiseptics for preventing surgical wound infections after clean surgery. Cochrane Database Syst Rev 2004; 3: CD003949. (STAT)

6. Shirahatti RG, Joshi RM, Vishwanath YK, Shinkre N, Rao S, Sankpal JS, Govindrajulu NK. Effect of preoperative skin preparation on post-operative wound infection. J Postgrad Med 1993; 39: 134-6. (RCT)

7. Robson MC, Duke WF, Krizek TJ. Rapid bacterial screening in the treatment of civilian wounds. J Surg Res 1973; 14: 426-30. (RCT)

8. Lammers RL, Fourre M, Callaham ML, Boone $\mathrm{T}$. Effect of povidone-iodine and saline soaking on bacterial counts in acute, traumatic, contaminated wounds. Ann Emerg Med 1990; 19: 709-14. (RCT)

\section{\#5: GUIDELINES TO DECREASE IMPEDIMENTS TO ACUTE WOUND HEALING CAUSED BY MECHANICAL FACTORS DURING WOUND REPAIR}

Preamble: Mechanical factors play an important and often underappreciated role in acute wound healing. Primary closure of an incision stabilizes distractive forces to allow wound healing and an optimized anatomic result. Cellular studies confirm that mechanical load forces are an important signal for acute wound repair. When anatomic stability of a wound is achieved, a particular suture material or suturing technique is of secondary importance. The increased use of foreign material implants, such as meshes for hernia repair, are suggested to manipulate the mechanical environment of the acute wound, even to the point of promoting "tension-free" wound healing. Negative pressure wound therapy is increasingly applied to stabilize acute wounds and to support acute wound healing. Me- chanical micro-deformation of repair cells in the wound bed is thought to stimulate acute wound healing.

Guideline \#5.1: Primarily repaired wounds heal faster than wounds left open to heal by secondary intent. Healing following delayed primary closure also is faster than in wounds left open to heal by secondary intent.

\section{Level of evidence: I}

Principle: Primarily closed wounds are of a smaller volume and heal mainly by the synthesis of a new matrix. Wound contraction and epithelialization, as in an open wound healing by secondary intent, contribute a small part to primary wound healing. An open wound, healing by secondary intent, must synthesize granulation tissue to fill in the wound bed, contract at the wound periphery, and cover the surface area with epithelial cells. Wounds heal faster following delayed primary closure than by secondary intent, as well. The mechanical load forces transmitted through a primarily reconstructed wound will stimulate repair. Successful delayed primary closure requires that the acute wound be in bacterial balance. Primary repair should approximate, but not strangulate the incision. The type of suture material used does not matter, as long as the primary repair is anatomic and perfused.

\section{Evidence:}

1. Robson MC, Shaw RC, Heggers JP. The re-closure of postoperative incisional abscesses based on bacterial quantification of the wound. Ann Surg 1970; 171: 27982. (CLIN S)

2. Coulthard P, Worthington H, Esposito M, Elst M, Waes OJ. Tissue adhesives for closure of surgical incisions. Cochrane Wounds Group. Cochrane Database Syst Rev 2007; 4. (STAT)

3. Robson MC, Heggers JP. Delayed wound closures based on bacterial counts. J Surg Oncol 1970; 2: 37983. (CLIN S)

4. Santora TA, Rosylyn JJ. Incisional hernia. Surg Clin North Am 1993; 73: 557-70. (LIT REV)

5. McCallum I, King PM, Bruce J. Healing by primary versus secondary intention after surgical treatment for pilonidal sinus. Cochrane Wounds Group. Cochrane Database Syst Rev 2007; 4, (STAT)

6. Zafar M, John A, Khan Z, Allen SM, Marchbank AJ, Lewis CT, Dalrymple-Hay MJ, Kuo J, UnsworthWhite J. Single-layer versus multiple-layer closure of leg wounds after long saphenous vein harvest: a prospective randomized trial. Ann Thorac Surg 2005; 80: 2162-5. (RCT)

7. Handschel JG, Depprich RA, Dirksen D, Runte C, Zimmermann A, Kübler NR. A prospective comparison of octyl-2-cyanoacrylate and suture in standardized facial wounds. Int J Oral Maxillofac Surg 2006; 35: 318-23. (RCT)

8. Murtha AP, Kaplan AL, Paglia MJ, Mills BB, Feldstein ML, Ruff GL. Evaluation of a novel technique for wound closure using a barbed suture. Plast Reconstr Surg 2006; 117: 1769-80. (RCT)

9. Ridgway DM, Mahmood F, Moore L, Bramley D, Moore PJ. A blinded, randomised, controlled trial of stapled versus tissue glue closure of neck surgery incisions. Ann R Coll Surg Eng 2007; 89: 242-6. (RCT) 
10. Henry MC, Moss RL. Primary versus delayed wound closure in complicated appendicitis: an international systematic review and meta-analysis. Ped Surg Int 2005; 21: 625-30. (STAT)

11. Nichols RL, Smith JW, Robertson GD, Muzik AC, Pearce P, Ozmen V, McSwain NE Jr, Flint LM. Prospective alterations in therapy for penetrating abdominal trauma. Arch Surg 1993; 128: 55-63. (RCT)

Guideline \#5.2: Laparotomy fascial incisions heal best when repaired as a mass closure using a continuous suture placed at a suture-length-to-wound-length ratio of $4: 1$.

Level of evidence: I

Principle: All incisions are placed under a strain following repair. An abdominal wall laparotomy incision extends $10 \%$ in length following repair. A continuous suture line placed at a suture-length-to-wound-length ratio of $4: 1$ allows the suture line to physiologically extend with the incision. This prevents suture "pull through," which is the most common mechanism of suture failure. A 4:1 ratio also minimizes the amount of suture material required, reducing the foreign material inflammatory response in the healing wound. The appropriate suture-length-to-woundlength ratio also optimizes tension on the suture line, minimizing wound ischemia.

Evidence:

1. Cruse PJ, Foord R. A five-year prospective study of 23,649 surgical wounds. Arch Surg 1973; 107: 206-10. (STAT)

2. Weiland DE, Bay RC, Del Sordi S. Choosing the best abdominal closure by meta analysis. Am J Surg 1998; 176: 666-70. (STAT)

3. Jenkins TPN. The burst abdominal wound: a mechanical approach. Br J Surg 1976; 63: 873-6. (CLIN S)

4. Pollock AV, Evans M. Early prediction of late incisional hernias. Br J Surg 1989; 76: 953-4. (CLIN S)

5. Carlson MA. Acute wound failure. Wound healing. Surg Clin North Am 2001; 77: 607-35. (LIT REV)

6. Poole GV Jr. Mechanical factors in abdominal wound closure: the prevention of fascial dehiscence. Surgery 1985; 97: 631-9. (EXP)

7. Mudge M, Hughes LE. Incisional hernia: a 10 year prospective study of incidence and attitudes. Br J Surg 1985; 72: 70-1. (CLIN S)

8. Webster C, Neumayer L, Smout R, Horn S, Daley J, Henderson W, Khuri S. National Veterans Affairs Surgical Quality Improvement Program. Prognostic models of abdominal wound dehiscence after laparotomy. J Surg Res 2003; 109: 130-7. (STAT)

9. van't Riet M, Steyerberg EW, Nellensteyn J, Bonjer HJ, Jeekel J. Meta-analysis of techniques for closure of midline abdominal incisions. Br J Surg 2002; 89: 1350-6. (STAT)

10. Niggebrugge AH, Trimbos JB, Hermans J, Steup WH, Van De Velde CJ. Influence of abdominal-wound closure technique on complications after surgery: a randomised study. Lancet 1999; 353: 1563-7. (RCT)

Guideline \#5.3: The type of suture material used does not affect laparotomy wound healing. Permanent sutures may result in chronic wound sinus or fistula formation.
Level of evidence: I

Principle: As long as the suture is present until adequate wound breaking or tensile strength is obtained, the type of suture material used does not affect acute wound healing. Permanent sutures increase the risk of chronic wound complications such as fistula and sinus track formation. Braided, permanent suture is at highest risk for an acute wound complication.

\section{Evidence:}

1. Hopkinson GB, Bullen BR. Removable subcuticular skin suture in acute appendicitis: a prospective comparative clinical trial. Br Med J 1982; 284: 869. (RCT)

2. Houck JP, Rypins EB, Sarfeh IJ, Juler GL, Shimoda KJ. Repair of incisional hernia. Surg Gyn Obstet 1989; 169: 397-9. (RCT)

3. Carlson MA. Acute wound failure. Wound healing. Surg Clin North Am 2001; 77: 607-35. (LIT REV)

4. Myers MB, Cherry G, Heimburger S. Augmentation of wound tensile strength by early removal of sutures. Am J Surg 1969; 117: 338-41. (CLIN S)

5. Pickford IR, Brennan SS, Evans M, Pollock AV. Two methods of skin closure in abdominal operations: a controlled clinical trial. Br J Surg 1983; 70: 226-8. (CLIN S)

6. Larsen PN, Nielsen K, Schultz A, Mejdahl S, Larsen T, Moesgaard F. Closure of the abdominal fascia after clean and clean-contaminated laparotomy. Acta Chir Scand 1989; 155: 461-4. (RCT)

7. Savolainen H, Ristkari S, Mokka R. Early laparotomy wound dehiscence: a randomized comparison of three suture materials and two methods of fascial closure. Ann Chir Gyn 1988; 77: 111-3. (RCT)

8. Derzie AJ, Silvestri F, Liriano E, Benotti P. Wound closure technique and acute wound complications in gastric surgery for morbid obesity: a prospective randomized trial. J Am Coll Surg 2000; 191: 238-43. (RCT)

9. Ullrich F, Henningsen B, Bottcher W. Fascial closure of median laparotomy incisions with synthetic reabsorbable sutures (polyglycolic acid). Chirurg 1981; 52: 777-9. (RCT)

10. Bresler L, Courbey PJ, Feldman L, Bilweiss J, Tortuyaux JM, Rauch P, Boissel P, Grosdidier J. Results of a controlled trial comparing 3 suture threads at slow resorption for the closure of supra-umbilical midline laparotomies. Ann Chir 1995; 49: 544-8. (RCT)

Guideline \#5.4: Soft tissue prostheses reduce the incidence of wound failure and recurrence following hernia repair.

Level of evidence: I

Principle: The recurrence rate following inguinal hernia repairs using autologous tissues ranges from 5 to $25 \%$ in most series. The recurrence rate following primary incisional hernia repair using autologous tissues is even worse, ranging from 20 to $60 \%$. The introduction of synthetic soft tissue prostheses to inguinal and incisional hernia repair has significantly reduced recurrence rates across general surgery. The prevailing view is that the mechanism for the reduced hernia recurrence rates is the reduction of tension along suture lines when using a soft-tissue prosthesis (mesh). 


\section{Evidence:}

1. Luijendijk RW, Hop WCJ, van den Tol MP, de Lange DC, Braaksma MM, Ijzermans JN, Boelhouwer RU, de Vries BC, Salu MK, Wereldsma JC, Bruijninckx CM, Jeekel J. A comparison of suture repair with mesh repair for incisional hernia. $N$ Engl J Med 2000; 343: 392-8. (RCT)

2. Burger WA, Luijendijk, RW, Hop Wim CJ, Halm JA, Verdaasdonk EG, Jeekel J. Long-term follow-up of a randomized controlled trial of suture versus mesh repair of incisional hernia. Ann Surg 2004; 24: 578-85. (RCT)

3. Flum DR, Horvath K, Koepsell T. Have outcomes of incisional hernia repair improved with time? A population based analysis. Ann Surg 2003; 237: 129-35. (STAT)

4. Korenkov M, Sauerland S, Arndt M, Bograd L, Neugebauer EA, Troidl H. Randomized clinical trial of suture repair, polypropylene mesh or autodermal hernioplasty for incisional hernia. Br J Surg 2002; 89: 506. (CLIN S)

5. van Veen RN, Wijsmuller AR, Vrijland WW, Hop WC, Lange JF, Jeekel J. Long-term follow-up of a randomized clinical trial of non-mesh versus mesh repair of primary inguinal hernia. Br J Surg 2007; 94: 506-10. (RCT)

Guideline \#5.5: Negative pressure therapy mechanically stabilizes the distractive forces of an open acute wound and supports healing. Negative pressure therapy can also stabilize an open abdomen (laparostomy), minimizing wound size and supporting closure of the abdominal wall.

\section{Level of evidence: II}

Principle: Distractive tissue forces may act to keep a wound open, with vectors that oppose contraction, thereby delaying healing. This phenomenon is especially true with the therapeutic laparostomy, or "open abdomen." Distractive force from the rectus muscle components and lateral oblique muscles act to keep the laparostomy open, leading to incisional hernia formation and potential loss of abdominal, peritoneal volume (domain). Negative pressure dressings can oppose these distractive soft tissue vectors and stabilize an acute wound.

\section{Evidence:}

1. Armstrong DG, Lavery LA, Diabetic Foot Study Consortium. Negative pressure wound therapy after partial diabetic foot amputation: a multicentre, randomised controlled trial. Lancet 2005; 366: 1704-10. (RCT)

2. Perez D, Wildi S, Demartines N, Bramkamp M, Koehler C, Clavien PA. Prospective evaluation of vacuumassisted closure in abdominal compartment syndrome and severe abdominal sepsis. J Am Coll Surg 2007; 205: 586-92. (CLIN S)

3. Dakin J, Thompson S. Use of topical negative pressure therapy with an abdominal dressing in management of a laparostomy. J Wound Care 2006; 15: 386-8. (RET$\mathrm{RO}$ S)

4. Quah HM, Maw A, Young T, Hay DJ. Vacuum-assisted closure in the management of the open abdomen: a report of a case and initial experiences. J Tissue Viabil 2004; 14: 59-62. (RETRO S)
5. Steenvoorde $\mathrm{P}$, van Engeland A, Bonsing B, Bonsing B, da Costa SA, Oskam J. Combining topical negative pressure and a Bogota bag for managing a difficult laparostomy. $J$ Wound Care 2004; 13: 142-3. (RETRO S)

6. Chorbadjian M, Bown M, Graham C, Sayers R. Laparostomy healing by secondary intention after ruptured abdominal aortic aneurysm repair. J Tissue Viabil 2004; 14: 24-7. (RETRO S)

Guideline \#5.6: External or internal retention sutures do not prevent dehiscence or incisional hernia formation. Retention sutures do not improve laparotomy wound outcomes.

\section{Level of evidence: I}

Principle: The incidence of clinically recognized acute laparotomy wound failure and dehiscence is at least $1 \%$, with a mortality of $>50 \%$. The incidence of unrecognized acute laparotomy wound failure and primary incisional hernia formation is at least $11 \%$. Comorbidities such as multiple trauma and wound contamination increase the risk of acute laparotomy wound failure. Purely mechanical efforts to stabilize abdominal wall repairs during primary closure are generally unsuccessful.

\section{Evidence:}

1. Wittmann DH, Aprahamian C, Bergstein JM. Etappenlavage: advanced diffuse peritonitis managed by planned multiple laparotomies utilizing zippers, slide fastener, and Velcro analogue for temporary abdominal closure. World J Surg 1990; 14: 218-26. (RETRO S)

2. Irvin TT, Stoddard CJ, Greaney MG, Duthie HL. Abdominal wound healing: a prospective clinical study. $\mathrm{Br}$ Med J 1977; 2: 351-2. (RCT)

3. Hubbard TB, Rever WB. Retention sutures in the closure of abdominal incisions. Am J Surg 1972; 124: 37880. (RCT)

4. Rink AD, Goldschmidt D, Dietrich J, Nagelschmidt M, Vestweber KH. Negative side-effects of retention sutures for abdominal wound closure. A prospective randomised study. Eur J Surg-Acta Chir 2000; 166: 932-7. (RCT)

Guideline \#5.7: Transverse laparotomy incisions do not form fewer incisional hernias than midline laparotomy incisions.

Level of evidence: I

Principle: The predominant, load-bearing collagen fibers of the abdominal wall are transversely oriented. Incisions parallel to these fibers are least destructive in terms of loss of mechanical integrity. Transverse laparotomy closures encircle these same load-bearing fibers, maximizing mechanical integrity. Although theoretically the mechanical integrity is maximized in the transverse incision, laparotomy incisional herniation occurs at similar rates regardless of incisional orientation.

\section{Evidence:}

1. DuBay D, Franz MG. Acute wound healing: the biology of acute wound failure. Surg Clin North Am 2003; 83: 463-81. (LIT REV)

2. Carlson M. Acute wound failure. Wound healing. Surg Clin North Am 2001; 77: 607-35. (LIT REV) 
3. Gislason H, Gronbech JE, Soreide O. Burst abdomen and incisional hernia after major gastrointestinal operations: comparison of 3 closure techniques. Eur $J$ Surg 1995; 161: 349-54. (CLIN S)

4. Brown SR, Goodfellow PB. Transverse verses midline incisions for abdominal surgery. Cochrane Colorectal Cancer Group. Cochrane Database Syst Rev 2007; 4. (STAT)

5. Halasz NA. Dehiscence of laparotomy wounds. Am J Surg 1968; 116: 210-4. (CLIN S)

6. Del Junco T, Lange HJ. Abdominal wound disruption with eventration: report of forty cases. Am J Surg 1956; 92: 271-86. (CLIN S)

7. Mäkelä JT, Kiviniemi H, Juvonen T, Laitinen S. Factors influencing wound dehiscence after midline laparotomy. Am J Surg 1995; 170: 387-90. (CLIN S)

8. Poole GV Jr. Mechanical factors in abdominal wound closure: the prevention of fascial dehiscence. Surgery 1985; 97: 631-40. (CLIN S)

9. Riou JP, Cohen JR, Johnson H Jr. Factors influencing wound dehiscence. Am J Surg 1992; 163: 324-30. (CLIN S)

10. Ellis H, Coleridge-Smith PD, Joyce AD. Abdominal incisions - vertical or transverse? Postgrad Med J 1984; 60: 407-10. (RCT)

11. Greenall MJ, Evans M, Pollock AV. Midline or transverse laparotomy? A random controlled clinical trial. Part I: Influence on healing. Br J Surg 1980; 67: 18890. (RCT)

\section{\#6: GUIDELINES TO DECREASE THE IMPEDIMENT TO ACUTE WOUND HEALING CAUSED BY SYSTEMIC IMMUNE DEFICIENCIES}

Preamble: The cellular and humoral inflammatory immune response is a vital part of the mechanism of normal wound healing. Systemic immune deficiency diseases such as HIV infection or the acquired immunodeficiency syndrome (AIDS) and hypogammaglobulinemia have been associated with acute wound healing defects. The increased volume of solid organ and bone marrow transplantation has led to a widespread use of immunosuppressant drugs. Leukopenia may be the result of hematologic diseases or iatrogenic bone marrow suppression. Pathological or iatrogenic immunosuppression impairs acute wound healing.

Guideline \#6.1: HIV seropositive patients, especially those with AIDS, should be maximally medically treated for that disease whenever possible before elective operations. Antiretroviral therapy should be initiated, viral load minimized, and absolute lymphocyte count maximized. Effective prophylaxis against wound infection should be used.

Level of evidence: I

Principle: The effect of HIV infection on acute wound healing is multifactorial. Normal cellular immunity is required for normal acute wound healing. A complicating wound infection or associated systemic infection will impair acute wound healing. Finally, progressive malnutrition or hypoalbuminemia is an impediment to acute wound healing.

\section{Evidence:}

1. Davis PA, Corless DJ, Gazzard BG, Wastell C. Increased risk of wound complications and poor healing following laparotomy in HIV-seropositive and AIDS patients. Dig Surg 1999; 16: 60-7. (CLIN S)

2. Nadal SR, Manzione CR, Galvao VM, Salim VR, Speranzini MB. Healing after anal fistulotomy: a comparative study between HIV + and HIV - patients. Dis Colon Rectum 1998; 41: 177-9. (CLIN S)

3. Lord RV. Anorectal surgery in patients infected with human immunodeficiency virus: factors associated with delayed wound healing. Ann Surg 1997; 226: 92-9. (CLIN S)

4. Luck JV. Orthopaedic surgery in the HIV positive patient: complications and outcome. Instr Course Lect 1994; 43: 543-9. (CLIN S)

5. Davis PA, Wastell D. A comparison of biomechanical properties of excised mature scars from HIV patients and non-HIV controls. Am J Surg 2000; 180: 217-22. (EXP)

6. Pankhurst CL, Lewis DA, Clark DT. Prophylactic application of an intra-alveolar socket medicament to reduce postextraction complications in HIV-seropositive patients. Oral Surg Oral Med Oral Path 1994; 77: 33133-4. (RCT)

7. Harrison WJ, Lewis CP, Lavy CB. Wound healing after implant surgery in HIV-positive patients. $J$ Bone $J t$ Surg 2002; 84: 802-6. (CLIN S)

8. Morandi E, Merlini D, Salvaggio A, Foschi D, Trabucchi E. Prospective study of healing time after hemorrhoidectomy: influence of HIV infection, acquired immunodeficiency syndrome, and anal wound infection. Dis Colon Rectum 1999; 42: 1140-4. (CLIN S)

9. Ortega KL, Rezende NP, Araujo NS, Magalhaes MH. Effect of topical antimicrobial paste on healing after extraction of molars in HIV positive patients. $\mathrm{Br} \mathrm{J} \mathrm{Oral}$ Maxillofac Surg 2007; 45: 27-9. (RCT)

Guideline \#6.2: Immunosuppressant drug activity (level) should be minimized whenever possible during surgical procedures and until the acute wound is healed. In particular, steroid doses should be minimized before wounding and during wound healing. However, if an emergency procedure is necessary for a patient on steroids, the steroids must be supported throughout the procedure and weaned postoperatively.

\section{Level of evidence: I}

Principle: The humoral and cellular inflammatory response is a fundamental part of the mechanism of acute wound healing. Defects in the early humoral and cellular immune response will increase the risk for both wound infection and acute, mechanical wound failure.

\section{Evidence:}

1. Hunt T. Disorders of wound healing. World J Surg 1980; 4: 271-7. (LIT REV)

2. Stephens FO, Dunphy JE, Hunt TK. Effect of delayed administration of corticosteroids on wound contraction. Ann Surg 1971; 173: 21421-8. (EXP) 
3. Gupta A, Jain GK, Raghubir R. A time course study for the development for an immunocompromised wound model using hydrocortisone. J Pharmacol Toxicol Methods 1999; 41: 183-7. (EXP)

4. Karatas GU, Yakupoglu U, Yakupoglu YK, Kocak H, Yavuz A, Dinckan A, Tuncer M, Demirbas A, Yakupoglu G, Ersoy FF, Gurkan A. Sirolimus as primary immunosuppression agent in kidney transplant recipients: Akdeniz University experience. Transplant Proc 2005; 37: 3006-8. (CLIN S)

5. Anil Kumar MS, Heifets M, Fyfe B, Saaed MI, Moritz MJ, Parikh MH, Kumar A. Comparison of steroid avoidance in tacrolimus/mycophenolate mofetil and tacrolimus/sirolimus combination in kidney transplantation monitored by surveillance biopsy. Transplantation 2005; 80: 807-14. (CLIN S)

6. Lo A, Egidi MF, Gaber LW, Gaber AO. Observations on the use of sirolimus and tacrolimus in high-risk renal transplant recipients. Transplant Proc 2003; 35 (Suppl.): 105S-8S. (CLIN S)

7. Kuypers DR. Benefit-risk assessment of sirolimus in renal transplantation. Drug Safety 2005; 28: 153-81. (LIT REV)

Guideline \#6.3: Leukopenia should be corrected whenever possible before an elective surgical procedure. Granulocyte-monocyte colony-stimulating growth factors or blood transfusion may be considered.

Level of evidence: II

Principle: Wound infection delays acute wound healing. White blood cells are also sources for tissue growth factors. Clinically and experimentally, macrophages are required for normal wound healing. Abnormal wound healing occurs in the setting of leukopenia.

\section{Evidence:}

1. Elihu A, Gollin G. Complications of implanted central venous catheters in neutropenic children. Am Surg 2007; 73: 1079-82. (CLIN S)

2. Shirafuji T, Oka T, Sawada T, Tamura K, Kishimoto K, Yamamoto S, Nagayasu T, Takahashi T, Ayabe H. The importance of peripheral blood leukocytes and macrophage infiltration on bronchial wall wound healing in rats treated preoperatively with anticancer agents. Surg Today 2001; 31: 308-16. (EXP)

3. Li Z, Burns AR, Smith CW. Two waves of neutrophil emigration in response to corneal epithelial abrasion: distinct adhesion molecule requirements. Invest Ophthal Visual Sci 2006; 47: 1947-55. (EXP)

4. Borregaard N, Theilgaard-Monch K, Cowland JB, Ståhle M, Sørensen $\mathrm{OE}$. Neutrophils and keratinocytes in innate immunity - cooperative actions to provide antimicrobial defense at the right time and place. J Leukoc Biol 2005; 77: 439-43. (EXP)

5. Vettenranta K, Hovi L, Makipernaa A, Jalanko H, Saarinen-Pihkala UM. Neutrophil regeneration precedes healing of tissue destruction, as indicated by serum C-reactive protein, in children with cancer recovering from neutropenic fever. Acta Paediatr 2002; 91: 915-9. (CLIN S)

6. Cody DT II, Funk GF, Wagner D, Gidley PW, Graham SM, Hoffman HT. The use of granulocyte colony stimulating factor to promote wound healing in a neutropenic patient after head and neck surgery. Head Neck 1999; 21: 172-5. (RETRO S)

7. Mayer B, Rösken F, Lepper A, Wanner GA, Menger MD. rG-CSF improves tissue regeneration in neutropenia-induced disorders of wound healing. Langenbecks Arch Chir 1998; 115 (Suppl. I): 469-70. (EXP)

8. Masucci G. New clinical applications of granulocytemacrophage colony-stimulating factor. Med Oncol 1996; 13: 149-54. (LIT REV)

9. Jyung RW, Wu L, Pierce GF, Mustoe TA. Granulocytemacrophage colony-stimulating factor and granulocyte colony-stimulating factor: differential action on incisional wound healing. Surgery 1994; 115: 325-34. (EXP)

10. Besner GE, Glick PL, Karp MP, Wang WC, Lobe TE, White CR, Cooney DR. Recombinant human granulocyte colony-stimulating factor promotes wound healing in a patient with congenital neutropenia. $J$ Pediatr Surg 1992; 27: 288-91. (RETRO S)

11. Schaffer MR, Barbul A. Lymphocyte function in wound healing and following injury. Br J Surg 1998; 85: 444-60. (LIT REV)

Guideline \#6.4: Blood transfusions have an immunosuppressant effect and can delay wound healing. Blood transfusions should be minimized before and following wounding.

Level of evidence: I

Principle: Tolerance of blood transfusions requires a relative immunosuppressed response on the part of the host (transfusion recipient). Perioperative blood transfusions are associated with worse outcomes in surgical oncology and trauma. The minimum tissue concentration of oxygen $\left(\mathrm{TcO}_{2}\right)$ required for wound healing can be maintained at lower serum hematocrits.

Evidence:

1. Tadros T, Wobbes T, Hendriks T. Blood transfusion impairs the healing of experimental intestinal anastomoses. Ann Surg 1992; 215: 276-81. (EXP)

2. Rappolee DA, Mark D, Banda MJ, Werb Z. Wound macrophages express TGF-beta and other growth-factors in vivo: analysis by mRNA phenotyping. Science 1988; 241: 708-12. (EXP)

3. Thornton FJ, Schaffer MR, Barbul A. Wound healing in sepsis and trauma. Shock 1997; 8: 391-401. (LIT REV)

4. Schaffer MR, Barbul A. Lymphocyte function in wound healing and following injury. Br J Surg 1998; 85: 444-60. (LIT REV)

5. Tartter P. Immunologic effects of blood transfusion. Immunol Invest 1995; 24: 2777-88. (LIT REV)

6. Ohwada S, Sato Y, Sato N, Toyama Y, Okano T, Nakasone Y, Ogawa T, Morishita Y. Effect of transfusion in gastrointestinal anastomotic wound healing and leukocyte function in rats. Eur Surg Res 2000; 32: 353-8. (EXP)

7. Apostolidis SA, Michalopoulos AA, Hytiroglou PM, Papadopoulos BN, Fachantidis EP, Basdanis GA, Catsohis CD. Prevention of blood-transfusion-induced impairment of anastomotic healing by leukocyte depletion in rats. Eur J Surg 2000; 166: 562-7. (EXP) 
8. Artioukh DY, Smith RA, Gokul K. Risk factors for impaired healing of the perineal wound after abdominoperineal resection of rectum for carcinoma. Colorectal Dis 2007; 9: 362-7. (CLIN S)

9. Brown CV, Velmahos GC, Neville AL, Rhee P, Salim A, Sangthong B, Demetriades D. Hemodynamically "stable" patients with peritonitis after penetrating abdominal trauma: identifying those who are bleeding. Arch Surg 2005; 140: 767-72. (CLIN S)

10. Weber EW, Slappendel R, Prins MH, van der Schaaf DB, Durieux ME, Strümper D. Perioperative blood transfusions and delayed wound healing after hip replacement surgery: effects on duration of hospitalization. Anesth Analg 2005; 100: 1416-21. (CLIN S)

11. Okano T, Ohwada S, Sato Y, Sato N, Toyama Y, Nakasone Y, Ogawa T, Morishita Y. Blood transfusions impair anastomotic wound healing, reduce luminol-dependent chemiluminescence, and increase interleukin-8. Hepato-Gastroenterology 2001; 48: 1669-74. (EXP)

12. Mandai R, Eguchi Y, Tanaka M, Sai Y, Nosaka S. Effects of profound hemodilution on small-intestinal wound healing in rabbits. J Surg Res 2001; 99: 107-13. (EXP)

13. Ohwada S, Sato Y, Sato N, Toyama Y, Okano T, Nakasone Y, Ogawa T, Morishita Y. Effects of transfusion on gastrointestinal anastomotic wound healing and leukocyte function in rats. Eur Surg Res 2000; 32: 353-8. (EXP)

14. Chmell MJ, Schwartz HS. Analysis of variables affecting wound healing after musculoskeletal sarcoma resections. J Surg Oncol 1996; 61: 185-9. (RETRO S)

\section{\# 7: GUIDELINES TO DECREASE THE IMPEDIMENT TO ACUTE WOUND HEALING CAUSED BY CANCER AND ITS TREATMENT}

Preamble: Malignant diseases will soon overtake cardiovascular disease as the leading cause of mortality in the United States. Malignant neoplasia is fundamentally dysregulated cellular proliferation, while wound healing represents regulated or controlled cellular proliferation. The mechanism of cancer therapy, therefore, usually involves the inhibition of cellular proliferation and function, which also will impair or prevent wound healing.

Guideline \#7.1: Chemotherapeutic drugs impair wound healing. Attempts should be made to maximize the time between neo-adjuvant and adjuvant therapies and surgical wounding.

Level of evidence: I

Principle: The most common chemotherapeutic agents are cytotoxic (nitrogen mustards and methylating agents), antiproliferative (microtubule stabilizers and DNA synthesis inhibitors), or antimetabolic (folic acid synthesis inhibitors). All of these pathways are normally activated during normal wound healing (benign neoplasia). Chemotherapeutic drugs therefore impair wound healing by the same mechanisms that they inhibit malignant cell growth.
Evidence:

1. Shirafuji T, Oka T, Sawada T, Tamura K, Nagayasu T, Takeya M, Yoshimura T, Ayabe H. Effects of induction therapy on wound healing at bronchial anastomosis sites in rats. Jpn J Thorac Cardiovasc Surg 2003; 51: 217-24. (EXP)

2. Shamberger RC, Devereux DF, Brennan MF. The effect of chemotherapeutic agents on wound healing. Int Adv Surg Oncol 1981; 4: 15-58. (LIT REV)

3. Best PJ, Daoud MS, Pittelkow MR, Petitt RM. Hydroxyurea-induced leg ulceration in 14 patients. Ann Intern Med 1998; 128: 29-32. (RETRO S)

4. Coleman JJ III, Walker AP, Didolkar MS. Treatment of adriamycin-induced skin ulcers: a prospective controlled study. J Surg Oncol 1983; 22: 129-35. (CLIN S)

5. Cohen MH, Gootenberg J, Keegan P, Pazdur R. FDA drug approval summary: bevacizumab plus FOLFOX 4 as second-line treatment of colorectal cancer. Oncologist 2007; 12: 356-61. (RCT)

6. Arbeit JM, Hilaris BS, Brennan MF. Wound complications in the multimodality treatment of extremity and superficial truncal sarcomas. J Clin Oncol 1987; 5: 480-8. (RCT)

7. Graf W, Ivarsson M, Gerdin B, Hellsing K, Påhlman L, Glimelius B. The influence of early postoperative intraperitoneal chemotherapy on human wound healing. J Surg Res 1994; 57: 394-400. (CLIN S)

8. Ariyan S, Craft RL, Goldberg NH. An experimental model to determine the effects of adjuvant therapy on the incidence of postoperative wound infection: II. Evaluating preoperative chemotherapy. Plast Reconstr Surg 1980; 65: 338-45. (EXP)

9. Ferguson MK. The effect of antineoplastic agents on wound healing. Surg Gynecol Obstet 1982; 154: 421-9. (LIT REV)

10. Cohen SC, Gabelnick HL, Johnson RK, Goldin A. Effects of antineoplastic agents on wound healing in mice. Surgery 1975; 78: 238-44. (EXP)

11. Desprez JD, Kiehn CL. The effects of cytoxan (cyclophosphamide) on wound healing. Plast Reconstr Surg Transplant Bull 1960; 26: 301-8. (LIT REV)

12. Cohen SC, Gabelnick HL, Johnson RK, Goldin A. Effects of cyclophosphamide and adriamycin on the healing of surgical wounds in mice. Cancer 1975; 36: 1277-81. (EXP)

13. Rath H, Enquist IF. The effect of thio-TEPA on wound healing. Arch Surg 1959; 79: 812-4. (CLIN S)

14. Farhat SM, Miller DM, Musselman MM. Effect of triethylenethiophosphoramide (thio-TEPA) upon healing abdominal wounds. Arch Surg 1959; 78: 72931. (EXP)

15. Hardesty WH. The effect of cytotoxic drugs on wound healing in rats. Cancer Res 1958; 18: 581-4. (EXP)

16. Fisher B, Ravdin RG, Ausman RK, Slack NH, Moore GE, Noer RJ. Surgical adjuvant chemotherapy in cancer of the breast: results of a decade of cooperative investigation. Ann Surg 1968; 168: 337-56. (STAT)

17. Mrazek R, Economou S, McDonald GO, Slaughter DP, Cole WH. Prophylactic and adjuvant use of nitrogen mustard in the surgical treatment of cancer. Ann Surg 1959; 150: 745-55. (CLIN S) 
18. Falcone RE, Nappi JF. Chemotherapy and wound healing. Surg Clin North Am 1984; 64: 779-94. (LIT REV)

19. Hendricks T, Martens MF, Huyben CM, Wobbes T. Inhibition of basal and TGF beta-induced fibroblast collagen synthesis by antineoplastic agents. Implications for wound healing. Br J Cancer 1993; 67: 545-50. (EXP)

20. Devereux DF, Thibault L, Boretos J, Brennan MF. The quantitative and qualitative impairment of wound healing by adriamycin. Cancer 1979; 43: 9328. (EXP)

21. Devereux DF, Kent H, Brennan MF. Time dependent effects of adriamycin and $\mathrm{x}$-ray therapy on wound healing in the rat. Cancer 1980; 45: 2805-10. (EXP)

22. Ehrlich HP, Hunt TK. Effects of cortisone and vitamin A on wound healing. Ann Surg 1968; 167: 324-8. (LIT REV)

Guideline \#7.2: Radiated tissue does not heal normally. Efforts should be made to operate through nonradiated tissue, or to optimize the healing of radiated tissue once it is injured.

\section{Level of evidence: I}

Principle: The healing of radiated tissue is impaired due mainly to fibrotic microangiopathy. The result is subthreshold tissue oxygen levels for normal acute wound healing. Technically, tissue planes are distorted due to fibrosis. Healing may be improved by increasing tissue oxygen levels, as with hyperbaric oxygen therapy.

\section{Evidence:}

1. Michalowski AS. On radiation damage to normal tissues and its treatment. II. Anti-inflammatory drugs. Acta Oncol 1994; 33: 139-57. (LIT REV)

2. Halperin EC, Gaspar L, George S, Darr D, Pinnell S. A double-blind, randomized, prospective trial to evaluate topical vitamin $\mathrm{C}$ solution for the prevention of radiation dermatitis. CNS Cancer Consortium. Int $J$ Radiat Oncol Biol Phys 1993; 26: 413-6. (RCT)

3. Kouvaris JR, Kouloulias VE, Plataniotis GA, Balafouta EJ, Vlahos LJ. Dermatitis during radiation for vulvar carcinoma: prevention and treatment with granulocyte-macrophage colony-stimulating factor impregnated gauze. Wound Rep Regen 2001; 9: $187-$ 93. (CLIN S)

4. Wong RKS, Tandan V, De Silva S, Figueredo A. Preoperative radiotherapy and curative surgery for the management of localized rectal carcinoma. Cochrane Colorectal Cancer Group. Cochrane Database Syst Rev 2007; 4. (STAT)

5. van Doorn HC, Ansink A, Verhaar-Langereis M, Stalpers L. Neoadjuvant chemoradiation for advanced primary vulvar cancer. Cochrane Gynaecological Cancer Group. Cochrane Database Syst Rev 2007; 4. (STAT)

6. Bennett MH, Feldmeier J, Hampson N, Smee R, Milross $\mathrm{C}$. Hyperbaric oxygen therapy for late radiation tissue injury. Cochrane Gynaecological Cancer Group. Cochrane Database Syst Rev 2007; 4. (STAT)

7. Hillmann A, Ozaki T, Rübe C, Hoffmann C, Schuck A, Blasius S, Haas A, Jürgens H, Winkelmann W. Surgical complications after preoperative irradiation of Ewing's sarcoma. J Cancer Res Clin Oncol 1997; 123: 57-62. (CLIN S)

8. Bernstein EF, Sullivan FJ, Mitchell JB, Salomon GD, Glatstein E. Biology of chronic radiation effects on tissues and wound healing. Clin Plast Surg 1993; 20: 435-53. (LIT REV)

9. Mendelsohn FA, Divino CM, Reis ED, Kerstein MD. Wound care after radiation therapy. Adv Skin Wound Care 2002; 15: 216-24. (LIT REV)

10. Dobbs WGH. A statistical study of the effects of roentgen rays on wound healing. Am J Roentgenol 1939; 41: 625-32. (EXP)

11. Kindwall EP. Hyperbaric oxygen's effect on radiation necrosis. Clin Plast Surg 1993; 20: 473-83. (LIT REV)

12. Luce EA. The irradiated wound. Surg Clin North Am 1984; 64: 821-9. (LIT REV)

13. Marcial VA, Gelber R, Kramer S, Snow JB, Davis LW, Vallecillo LA. Does preoperative irradiation increase the rate of surgical complications in carcinoma of the head and neck? Cancer 1982; 49: 1297-301. (LIT REV)

14. Joseph DL, Shumrick DL. Risks of head and neck surgery in previously irradiated patients. Arch Otolaryngol 1973; 97: 381-4. (LIT REV)

15. Vikram B. Importance of the time interval between surgery and postoperative radiation therapy in the combined management of head and neck cancer. Int $J$ Radiat Oncol Biol Phys 1979; 5: 1837-40. (RETRO S)

16. Isaacs JH Jr., Thompson WB, Cassisi NJ, Million RR. Postoperative radiation of open head and neck wounds. Laryngoscope 1987; 97 (Part 1): 267-70. (RETRO S)

17. Porock D. Factors influencing the severity of radiation skin and oral mucosal reactions: development of a conceptual framework. Eur $J$ Cancer Care (Engl) 2002; 116: 33-43. (LIT REV)

18. Martin M, Vozenin MC, Gault N, Crechet F, Pfarr CM, Lefaix JL. Coactivation of AP-1 activity and TGF-beta 1 gene expression in the stress response of normal skin cells to ionizing radiation. Oncogene 1997; 15: 981-9. (EXP)

Guideline \#7.3: Cancer patients may develop unique malnutrition syndromes (cancer cachexia). This is, in part, due to elevated tumor associated cytokine levels (tumor necrosis factor [TNF]). Enteral nutrient supplementation, but not parenteral nutrient supplementation, improves wound healing in cancer patients.

\section{Level of evidence: I}

Principle: Hypoalbuminemia is a well-established marker for surgical complications, including impaired wound healing. Cancer patients often express protein malnutrition. In addition, cancer patients may express a unique malnutrition syndrome, cancer cachexia or cancer anorexia. It is believed that part of the mechanism for this paraneoplastic syndrome is elevated stress or inflammatory cytokines, especially TNF- $\alpha$ (cachexin). Cancer cachexia is also associated with surgical complications and poor wound healing.

\section{Evidence:}

1. de Luis DA, Izaola O, Cuellar L, Terroba MC, Aller R. Randomized clinical trial with an enteral arginine- 
enhanced formula in early postsurgical head and neck cancer patients. Eur J Clin Nutr 2004; 58: 1505-8. (RCT)

2. Farreras N, Artigas V, Cardona D, Rius X, Trias M, González JA. Effect of early postoperative enteral immunonutrition on wound healing in patients undergoing surgery for gastric cancer. Clin Nutr 2005; 24 : 55-65. (RCT)

3. Milne AC, Potter J, Avenell A. Protein and energy supplementation in elderly people at risk from malnutrition. Cochrane Metabolic and Endocrine Disorders Group. Cochrane Database Syst Rev 2007; 4. (STAT)

4. Sako K, Lore JM, Kaufman S, Razack MS, Bakamjian V, Reese P. Parenteral hyperalimentation in surgical patients with head and neck cancer: a randomized study. J Surg Oncol 1981; 16: 391-402. (RCT)

5. Aoki K, Ikeda K, Sato N. Clinical appraisal of the additional total parenteral nutrition combined with postoperative enteral feeding on the patient of thoracic esophageal cancer surgery. Jpn J Gastroenterol Surg 2000; 33: 693-702. (RCT)

6. Ollenschläger G, Veill B, Thomas W, Konkol K, Bürger B. Tumor anorexia: causes, assessment, treatment. Recent Results Cancer Res 1991; 121: 249-59. (LIT REV)

7. The Veterans Affairs Total Parenteral Nutrition Cooperative Study Group. Perioperative total parenteral nutrition in surgical patients. N Engl J Med 1991; 325 : 525-32. (STAT)

8. Marino PL, Finnegan MJ. Nutrition support is not beneficial and can be harmful in critically ill patients. Crit Care Clin 1996; 12: 667-76. (CLIN S)

9. Fischer JE. Nutritional support in the seriously ill patient. Curr Prob Surg 1980; 8: 469-532. (LIT REV)

10. Moore FA, Feliciano DV, Andrassy RJ, McArdle AH, Booth FV, Morgenstein-Wagner TB, Kellum JM Jr., Welling RE, Moore EE. Early enteral feeding, compared with parenteral, reduces postoperative septic complications: the results of a meta-analysis. Ann Surg 1992; 216: 172-83. (STAT)

11. Rivadeneira DE, Evoy D, Fahey TJ III, Lieberman MD, Daly JM. Nutritional support of the cancer patient. CA Cancer J Clin 1998; 48: 69-80. (LIT REV)

12. Lawrence WT, Norton JA, Harvey AK, Gorschboth CM, Talbot TL, Grotendorst GR. Wound healing in sarcoma-bearing rats: tumor effects on cutaneous and deep wounds. J Surg Oncol 1987; 35: 7-12. (EXP)

13. Heys SD, Gough DB, Eremin O. Is nutritional support in patients with cancer undergoing surgery beneficial? Eur J Surg Oncol 1999; 22: 292-7. (LIT REV)

14. Nixon DW, Heymsfield SB, Cohen AE, Kutner MH, Ansley J, Lawson DH, Rudman D. Protein-calorie undernutrition in hospitalized cancer patients. Am J Med 1980; 66: 683-90. (CLIN S)

\section{\# 8: GUIDELINES TO DECREASE THE IMPEDIMENT TO ACUTE WOUND HEALING CAUSED BY SYSTEMIC CONDITIONS SUCH AS DIABETES MELLITUS, AGE, OBESITY, MALNUTRITRION, ETC.}

Preamble: There are systemic conditions or diseases that affect the ability of wounds to heal in an orderly and timely manner. Optimizing aspects of these conditions or diseases can aid in maximizing the wound healing trajectory, even when the condition or disease cannot be completely eliminated.

Guideline \#8.1: Optimizing glucose control improves wound healing.

Level of evidence: II

Principle: In patients with diabetes, wound healing is more likely to be optimal in the setting of good glucose control. Abnormal glucose levels also affect the character of infection.

\section{Evidence:}

1. Marston WA, Dermagraft Diabetic Foot Ulcer Study Group. Risk factors associated with healing chronic diabetic foot ulcers: the importance of hyperglycemia. Ostomy Wound Manage 2006; 52: 26-8. (RCT)

2. Rubinstein A, Pierce CE. Rapid healing of diabetic foot ulcers with a meticulous blood glucose control. Acta Diabetol Lat 1988; 25: 25-32. (CLIN S)

3. Lazar HL, Chipkin SR, Fitzgerald CA, Bao Y, Cabral $\mathrm{H}$, Apstein CS. Tight glycemic control in diabetic coronary artery bypass graft patients improves perioperative outcomes and decreases recurrent ischemic events. Circulation 2004; 109: 1497-52. (RCT)

4. Rai NK, Suryabhan, Ansari M, Kumar M, Shukla VK, Tripathi K. Effect of glycaemic control on apoptosis in diabetic wounds. J Wound Care 2005; 14 : 277-81. (CLIN S)

5. Robson MC, Heggers JP. Variables in host resistance pertaining to septicemia. I. Blood glucose level. $J \mathrm{Am}$ Geriatr Soc 1969; 17: 991-6. (CLIN S)

6. Blondet JJ, Beilman GJ. Glycemic control and prevention of perioperative infection. Curr Opin Crit Care 2007; 13: 421-7. (LIT REV)

7. Robson MC. A new look at diabetes mellitus and infection. Am J Surg 1970; 120: 681-2. (EXP)

8. Follak N, Kloting I, Merk H. Influence of diabetic metabolic state on fracture healing in spontaneously diabetic rats. Diabetes Metab Res Rev 2005; 21: 288-96. (EXP)

9. Duckworth WC, Fawcett J, Reddy S, Page JC. Insulin-degrading activity in wound fluid. J Clin Endocrinal Metab 2004; 89: 847-51. (EXP)

10. Beam HA, Parsons JR, Lin SS. The effects of blood glucose control upon fracture healing in the BB Wistar rat with diabetes mellitus. J Orthop Res 2002; 20: 1210-6. (EXP)

11. Verhofstad MH, Hendriks T. Complete prevention of impaired anastomatic healing in diabetic rats requires preoperative blood glucose control. Br J Surg 1996; 83: 1717-21. (EXP)

12. Spravchikov N, Sizyakov G, Gartsbein M, Accili D, Tennenbaum T, Wertheimer E. Glucose effects on skin keratinocytes: implications for diabetes skin complications. Diabetes 2001; 50: 1627-35. (EXP)

13. Greenhalgh DG. Wound healing and diabetes mellitus. Clin Plast Surg 2003; 30: 37-45. (LIT REV)

14. Golden SH, Peart-Vigilance C, Kao WH, Brancati FL. Perioperative glycemic control and the risk of infectious complications in a cohort of adults with diabetes. Diabetes Care 1999; 22: 1408-14. (CLIN S) 
15. Deveci M, Gilmont RR, Dunham WR, Mudge BP, Smith DJ, Marcelo CL. Glutathione enhances fibroblast collagen contraction and protects keratinocytes from apoptosis in hyperglycemic culture. $\mathrm{Br} J$ Dermatol 2005; 152: 217-24. (EXP)

Guideline \#8.2: Although older patients may have physiologic impairments in wound healing, the incidence of healing is similar to younger patients but at a slower rate.

Level of evidence: II

Principle: In elderly patients without other significant medical conditions, the rate of wound healing is normal or mildly impaired. Systemic and regional medical conditions are more common in the aged and account for many of the delays in healing.

\section{Evidence:}

1. Aschcroft GS, Horan MA, Ferguson MW. Aging is associated with reduced deposition of specific extracellular matrix components, an upregulation of angiogenesis, and an altered inflammatory response in a murine incisional wound healing model. J Invest Dermatol 1997; 108: 430-7. (EXP)

2. Fatah MF. The morbidity of split-skin graft donor sites in the elderly: the case for mesh-grafting the donor site. Br J Plast Surg 1984; 37: 184-90. (RCT)

3. Brem H, Tomic-Canic M, Tarnovskaya A, Ehrlich HP, Baskin-Bey E, Gill K, Carasa M, Weinberger S, Entero $\mathrm{H}$, Vladeck B. Healing of elderly patients with diabetic foot ulcers, venous stasis ulcers, and pressure ulcers. Surg Technol Int 2003; 11: 161-7. (LIT REV)

4. Quirinia A, Viidik A. The influence of age on the healing of normal and ischemic skin wounds. Mech Ageing Dev 1991; 58: 221-32. (EXP)

5. Gosain A, DiPietro LA. Aging and wound healing. World J Surg 2004; 28: 321-6. (LIT REV)

6. Gerstein AD, Phillips TJ, Rogers GS, Gilchrest BA. Wound healing and aging. Dermatol Clin 1993; 11: 74957. (LIT REV)

7. Van de Kerkhof PC, Van Bergen B, Spruijt K, Kuiper JP. Age-related changes in wound healing. Clin Exp Dematol 1994; 19: 369-74. (LIT REV)

8. Holt D, Kirk SJ, Regan MC, Hurson M, Lindblad WJ, Barbul A. Effect of age on wound healing in healthy humans. Surgery 1992; 112: 293-8. (EXP)

Guideline \#8.3: Obesity is associated with a higher incidence of wound complications. This should be considered when deciding whether to perform elective operations.

Level of evidence: II

Principle: There is an epidemic of obesity in the Western culture. Obesity is associated with an increased risk of surgical site infections, wound dehiscence, and hernia. Complications at sites distant from the wound also are increased.

\section{Evidence:}

1. Gendall KA, Raniga S, Kennedy R, Frizelle FA. The impact of obesity on outcome after major colorectal surgery. Dis Colon Rectum 2007; 50: 2223-37. (LIT REV)
2. Anaya DA, Dellinger EP. The obese surgical patient: a susceptible host for infection. Surg Infect (Larchmt) 2006; 7: 473-80. (LIT REV)

3. Bamgbade OA, Rutter TW, Nafiu OO, Dorje P. Postoperative complications in obese and nonobese patients. World J Surg 2007; 31: 556-60. (RETRO S)

4. Yap CH, Zimmet A, Mohajeri M, Yii M. Effect of obesity on early morbidity and mortality following cardiac surgery. Heart Lung Circ 2007; 16: 31-6. (CLIN S)

5. Kaye KS, Sloane R, Sexton DJ, Schmader KA. Risk factors for surgical site infections in older people. $J$ Am Geriatr Soc 2006; 54: 391-6. (RETRO S)

6. Gamboa-Bobadilla GM, Killingsworth C. Large-volume reduction mammoplasty: the effect of body mass index on postoperative complications. Ann Plast Surg 2007; 58: 246-9. (CLIN S)

7. Villavicencio MA, Sundt TM III, Daly RC, Dearani JA, McGregor CG, Mullany CJ, Orszulak TA, Puga FJ, Schaff HV. Cardiac surgery in patients with body mass index of 50 or greater. Ann Thorac Surg 2007; 83: 1403-11. (CLIN S)

8. Friedman ND, Sexton DJ, Connelly SM, Kaye KS. Risk factors for surgical site infection complicating laminectomy. Infect Control Hosp Epidemiol 2007; 28: 1060-5. (CLIN S)

9. Patel VI, Hamdan AD, Schermerhorn ML, Hile C, Dahlberg S, Campbell DR, LoGerfo FW, Pomposelli FB. Lower extremity arterial revascularization in obese patients. J Vasc Surg 2007; 46: 738-42. (CLIN S)

10. Derzie A, Silvestri F, Liriano E, Benott I. Wound closure technique and acute wound complications in gastric surgery for morbid obesity: a prospective randomized trial. J Am Coll Surg 2000; 191: 238-48. (RCT)

Guideline \#8.4: Nutrition must be adequate to provide metabolic support for healing. Weight and prealbumin and albumin levels are helpful in identifying patients who are malnourished and may need nutritional support.

\section{Level of evidence: I}

Principle: The nutritional status of most people will allow normal healing to occur. Elderly patients, those with gastrointestinal problems or other debilitating illnesses, and patients institutionalized in long-term care facilities are at greater risk for malnutrition. Obesity, low albumin, and low protein levels are associated with an increased risk of wound dehiscence and infection. Nutritional supplements, including proteins, carbohydrates, fats, vitamins, minerals, and trace elements, improve healing and reduce the likelihood of surgical site infection, wound dehiscence, and hernia.

\section{Evidence:}

1. Bourdel-Marchasson I, Barateau M, Rondeau V, Dequae-Merchadou L, Salles-Montaudon N, Emeriau JP, Manciet G, Dartigues JF. A multi-center trial of the effects of oral nutritional supplementation in critically ill older patients. GAGE Group. Group Aquitain 
Geriaritrique d'Evaluation. Nutrition 2000; 16: 1-5. (RCT)

2. Collins CE, Kershaw J, Brockington S. Effect of nutritional supplements on wound healing in homenursed elderly: a randomized trial. Nutrition 2005; 21 : 147-55. (RCT)

3. Braga M, Gianotti L, Nespoli L, Radaelli G, Di Carlo V. Nutritional approach in malnourished surgical patients: a prospective randomized study. Arch Surg 2002; 137: 174-80. (RCT)

4. Lee SK, Posthauer ME, Dorner B, Redovian V, Maloney MJ. Pressure ulcer healing with a concentrated, fortified, collagen protein hydrolysate supplement: a randomized controlled trial. Adv Skin Wound Care 2006; 19: 92-6. (RCT)

5. Waitzberg DL, Saito H, Plank LD, Jamieson GG, Jagannath P, Hwang TL, Mijares JM, Bihari D. Postsurgical infections are reduced with specialized nutrition support. World J Surg 2006; 30: 1592-604. (STAT)

6. Kirk SJ, Hurson M, Regan MC, Holt DR, Wasserkrug HL, Barbul A. Arginine stimulates wound healing and immune function in elderly human beings. Surgery 1993; 114: 155-9. (RCT)

7. Lansdown AB. Nutrition 2: a vital consideration in the management of skin wounds. Br J Nurs 2004; 13: 1199-210. (LIT REV)

8. Okada A, Takagi Y, Nezu R, Lee S. Zinc in clinical surgery - a research review. Jpn J Surg 1990; 20: 63544. (LIT REV)

9. Doweiko JP, Nompleggi DJ. The role of albumin in human physiology and pathophysiology. Part III: albumin and disease states. J Parenter Enteral Nutr 1991; 15: 476-83. (LIT REV)

10. Pedersen NW, Pedersen D. Nutrition as a prognostic indicator in amputations. A prospective study of 47 cases. Acta Orthop Scand 1992; 63: 675-8. (CLIN S)

11. Pollack SV. Wound healing: a review. III. Nutritional factors affecting wound healing. Dermatol Surg Oncol 1979; 5: 615-9. (LIT REV)

12. Del Savio GC, Zelicof SB, Wexler LM, Byrne DW, Reddy PD, Fish D, Ende KA. Preoperative nutritional status and outcome of elective total hip replacement. Clin Orthop Relat Res 1996; 32: 153-61. (CLIN S)

13. Riou JP, Cohen JR, Johnson H Jr. Factors influencing wound dehiscence. Am J Surg 1992; 163: 324-30. (RETRO S)

14. Greene KA, Wilde AH, Stulberg BN. Preoperative nutritional status of total joint patients. Relationship to postoperative wound complications. Arthroplasty 1991; 6: 321-5. (RETRO S)

15. Makela JT, Kiviniemi H, Juvonen $\mathrm{T}$, Laitinen $\mathrm{S}$. Factors influencing wound dehiscence after midline laparotomy. Am J Surg 1995; 170: 387-90. (RETRO S)

16. Shi HP, Wang SM, Zhang GX, Zhang YJ, Barbul A. Supplemental L-arginine enhances wound healing following trauma/hemorrhagic shock. Wound Rep Regen 2007; 15: 66-70. (EXP)

17. Williams JG, Barbul A. Nutrition and wound healing. Surg Clin North Am 2003; 83: 571-6. (LIT REV)

\section{\#9: GUIDELINES TO DECREASE THE IMPEDIMENT TO ACUTE WOUND HEALING CAUSED BY BURN INJURIES}

Preamble: Burn injury results in alterations in the normal function of all physiologic systems. These alterations can affect wound healing. The burn victim can have up to four types of wounds that require specialized treatment, and several of these wound types can coexist. The wounds include shallow partial-thickness wounds, which will epithelialize within 21 days; deep wounds that require removal of necrotic tissue and wound closure; donor-site wounds resulting from harvesting of skin grafts; and interstitial wounds resulting from meshed skin graft application. When the combination of these wounds covers a significant total body surface area (TBSA), the manner in which the wounds heal can be the final determinant of morbidity and mortality.

Guideline \#9.1: For deep burn wounds, early eschar excision and wound closure is indicated.

Level of evidence: I

Principle: Early removal of necrotic tissue decreases abnormalities to the immune system, decreases the risk of infection, improves survival, and initiates a normal healing trajectory.

Evidence:

1. Ong YS, Samuel M, Song C. Meta-analysis of early excision of burns. Burns 2006; 32: 145-50. (STAT)

2. Engrav LH, Heimbach DM, Reus JL, Harnar TJ, Marvin JA. Early excision and grafting vs. nonoperative treatment of burns of indeterminant depth: a randomized prospective study. J Trauma 1983; 23: 1001-4. (RCT)

3. Gray DT, Pine RW, Harnar TJ, Marvin JA, Engrav LH, Heimbach DM. Early surgical excision versus conventional therapy in patients with 20 to 40 percent burns. A comparative study. Am J Surg 1982; 144: 7680. (RCT)

4. Herndon DN, Barrow RE, Rutan RL, Rutan TC, Desai MH, Abston S. A comparison of conservative versus early excision therapies in severely burned patients. Ann Surg 1989; 209: 547-52. (RCT)

5. Herndon DN, Parks DH. Comparison of serial debridement and autografting and early massive excision with cadaver skin overlay in the treatment of large burns in children. J Trauma 1986; 26: 149-52. (RCT)

6. Sorensen B, Fisker NP, Steensen JP, Kalaja E. Acute excision or exposure treatment? Final results of a threeyear randomized controlled clinical trial. Scand J Plast Reconstr Surg 1984; 18: 87-93. (RCT)

7. Tompkins RG, Burke JF, Schoenfeld DA, Bondoc CC, Quinby WC Jr, Behringer GC, Ackroyd FW. Prompt eschar excision: a treatment system contributing to reduced burn mortality. A statistical evaluation of burn care at the Massachusetts General Hospital (1974 1984). Ann Surg 1986; 204: 272-81. (CLIN S)

8. Janzekovic $Z$. The burn wound from a surgical point of view. J Trauma 1975; 15: 42-62. (CLIN S)

9. Muangman P, Sullivan SR, Honari S, Engrav LH, Heimbach DM, Gibran NS. The optimal time for early 
excision in major burn injury. $J$ Med Assoc Thai 2006; 89: 29-36. (RETRO S)

Guideline \#9.2: Scald burns in children, burns in the elderly, burns in patients with severe inhalation injury, and burns of special areas (hands and face) may be considered exceptions to early excision and grafting of deep burns.

\section{Level of evidence: II}

Principle: Early excision and grafting can impose a significant insult to patients at the extremes of age or with significant comordid conditions such as smoke inhalation. It has been difficult to prove superior results for early excision and grafting of hand or facial burns.

\section{Evidence:}

1. Desai MH, Rutan RL, Herndon DN. Conservative treatment of scald burns is superior to early excision. $J$ Burn Care Rehabil 1991; 12: 482-4. (RCT)

2. Irei M, Abston S, Bonds E, Rutan T, Desai M, Herndon DN. The optimal time for excision of scald burns in toddlers. J Burn Care Rehabil 1986; 7: 508-10. (RETRO S)

3. Kirn DS, Luce EA. Early excision and grafting versus conservative management of burns in the elderly. Plast Reconstr Surg 1998; 102: 1013-7. (RETRO S)

4. Housinger T, Saffle J, Ward S, Warden G. Conservative approach to the elderly patient with burns. Am J Surg 1984; 148: 817-20. (RETRO S)

5. Ong YS, Samuel M, Song C. Meta-analysis of early excision of burns. Burns 2006; 32: 145-50. (STAT)

6. Edstrom L, Robson MC, Macchiaverna JR, Scala AD. Management of deep partial thickness dorsal hand burns. Orthoped Rev 1979; 8: 27-33. (RCT)

7. Salisbury RE, Wright P. Evaluation of early excision of dorsal burns of the hand. Plast Reconstr Surg 1982; 69: 670-5. (RCT)

8. Cole JK, Engrav LH, Heimbach DM, Gibran NS, Costa BA, Nakamura DY, Moore ML, Blayney CB, Hoover CL. Early excision and grafting of the face and neck burns in patients over 20 years. Plast Reconstr Surg 2002; 109: 1266-73. (CLIN S)

9. Fraulin FO, Illmayer SJ, Tredget EE. Assessment of cosmetic and functional result of conservative versus surgical management of facial burns. J Burn Care Rehabil 1996; 17: 19-29. (CLIN S)

Guideline \#9.3: When an excised burn TBSA is so large that donor sites for split-thickness skin grafts are insufficient, permanent skin substitutes can serve as skin replacement without fear of rejection.

Level of evidence: I

Principle: Skin substitutes that are not immunogenic can serve as permanent skin replacement without fear of rejection.

\section{Evidence:}

1. Pham C, Greenwood J, Cleland H, Woodruff P, Maddern $\mathrm{G}$. Bioengineered skin substitutes for management of burns: a systematic review. Burns 2007; 33: 946-57. (STAT)
2. Odessey R. Addendum: multicenter experience with cultured epidermal autograft for treatment of burns. $J$ Burn Care Rehabil 1992; 13: 174-80. (STAT)

3. Boyce ST, Goretsky MJ, Greenhalgh DG, Kagan RJ, Rieman MT, Warden GD. Comparative assessment of cultured skin substitute and native skin autograft for treatment of full-thickness burns. Ann Surg 1995; 222: 743-52. (RCT)

4. Rue LW, Cioffi WG, McManus WF, Pruitt BA. Wound closure and outcome in extensively burned patients treated with cultured autologous keratinocytes. J Trauma 1993; 34: 662-7. (CLIN S)

5. Barret JP, Wolf SE, Desai MH, Herndon DN. Costefficacy of cultured epidermal autografts in massive pediatric burns. Ann Surg 2000; 231: 869-76. (CLIN S)

6. Herndon DN, Rutan RL. Comparison of cultured epidermal autograft and massive excision with serial autografting plus homograft overlay. $J$ Burn Care Rehabil 1992; 13: 154-7. (CLIN S)

7. Arons JA, Wainwright DJ, Jordon RE. The surgical applications and implications of cultured human epidermis: a comprehensive review. Surgery 1992; 111:4 11. (LIT REV)

8. Heimbach D, Luterman A, Burke J, Cram A, Herndon D, Hunt J, Jordan M, McManus W, Solem L, Warden G. Artificial dermis for major burns: a multicenter randomized clinical trial. Ann Surg 1988; 208: 313-20. (RCT)

9. Branski LK, Herndon DN, Pereira C, Mlcak RP, Celis MM, Lee JO, Sanford AP, Norbury WB, Zhang $\mathrm{XJ}$, Jeschke MG. Longitudinal assessment of Integra in primary burn management: a randomized pediatric clinical trial. Crit Care Med 2007; 11: 2615-23. (RCT)

10. Heimbach DM, Warden GD, Luterman A, Jordan MH, Ozobia N, Ryan CM, Voigt DW, Hickerson WL, Saffle JR, DeClement FA, Sheridan RL, Dimick AR. Multicenter postapproval clinical trial of Integra dermal regeneration template for burn treatment. $J$ Burn Care Rehabil 2003; 24: 42-8. (CLIN S)

11. Wainwright DJ. Use of acellular allograft dermal matrix (AlloDerm) in the management of full-thickness burns. Burns 1995; 21: 243-8. (CLIN S)

Guideline \#9.4: Temporary skin substitutes are effective on partial-thickness burns while awaiting epithelialization and on excised full-thickness burns while awaiting skin graft application.

Level of evidence: I

Principle: Temporary biologic, synthetic, biosynthetic, or bioengineered dressings cannot provide permanent burn wound closure, but can maintain a wound free of infection until permanent wound closure occurs.

\section{Evidence:}

1. Pham C, Greenwood J, Cleland H, Woodruff P, Maddern $\mathrm{G}$. Bioengineered skin substitutes for the management of burns: a systematic review. Burns 2007; 33: 946-57. (STAT)

2. Noordenbos J, Dore C, Hansbrough JF. Safety and efficacy of transcyte for the treatment of partial-thickness burns. J Burn Care Rehabil 1999; 20: 275-81. (RCT) 
3. Kumar RJ, Kimble RM, Boots R, Pegg SP. Treatment of partial-thickness burns: a prospective, randomized trial using Transcyte. Aust NZ J Surg 2004; 74: 622-6. (RCT)

4. Hansbrough JF, Mozingo DW, Kealey GP, Davis M, Gidner A, Gentzkow GD. Clinical trials of a biosynthetic temporary skin replacement, dermagrafttransitional covering, compared with cryo-preserved human cadaver skin for temporary coverage of excised burn wounds. J Burn Care Rehabil 1997; 18: 43-59. (RCT)

5. Purdue GF, Hunt JL, Still JM Jr, Law EJ, Herndon DN, Goldfarb IW, Schiller WR, Hansbrough JF, Hickerson WL, Himel HN, Kealey GP, Twomey J, Missavage AE, Solem LD, Davis M, Totoritis M, Gentzkow GD. A multicenter clinical trial of a biosynthetic skin replacement, Dermagraft-TC, compared with cryopreserved human cadaver skin for temporary coverage of excised burn wounds. J Burn Care Rehabil 1997; 18: 527. (RCT)

6. Purdue GF, Hunt JL, Gillespie RW, Hansbrough JF, Dominic WJ, Robson MC, Smith DJ, MacMillan BG, Waymac JP, Herndon DN. Biosynthetic skin substitute versus frozen human cadaver allograft for temporary coverage of excised burn wounds. J Trauma 1987; 27: 155-7. (RCT)

7. Barret JP, Dziewulski P, Ramzy PI, Wolf SE, Desai $\mathrm{MH}$, Herndon DN. Biobrane versus 1\% silver sulfadiazine in second-degree pediatric burns. Plast Reconstr Surg 2000; 105: 62-5. (RCT)

8. Gerding RL, Emerman CL, Effron D, Lukens T, Imbembo AL, Fratianne RB. Outpatient management of partial-thickness burns: biobrane versus $1 \%$ silver sulfadiazine. Ann Emerg Med 1990; 19: 121-4. (RCT)

9. Lal S, Barrow RE, Wolf SE, Chinkes DL, Hart DW, Heggers JP, Herndon DN. Biobrane improves wound healing in burned children without increased risk of infection. Shock 2000; 14: 314-8. (CLIN S)

Guideline \#9.5: Peptide growth factors accelerate healing of the various types of wounds seen in the burn patient.

Level of evidence: I

Principle: Cytokines and growth factors that can accelerate epithelialization should benefit wound closure in wounds healing by epithelialization.

Evidence:

1. Smith PD, Polo M, Soler PM, McClintock JS, Maggi SP, Kim YJ, Ko F, Robson CM. Efficacy of growth factors in the accelerated closure of interstices in explanted meshed human skin grafts. J Burn Care Rehabil 2000; 21: 5-9. (EXP)

2. Fu X, Shen Z, Chen Y, Xie J, Guo Z, Zhang M, Sheng Z. Randomized placebo-controlled trial of use of topical bovine basic fibroblast growth factor for seconddegree burns. Lancet 1998; 352: 1661-4. (RCT)

3. Fu X, Shen Z, Chen Y, Xie J, Guo Z, Zhang M, Sheng $Z$. Recombinant bovine basic fibroblast growth factor accelerates wound healing in patients with burns, donor sites, and chronic dermal ulcers. Chin Med J 2000; 113: 367-71. (RCT)

4. Greenhalgh DG, Rieman M. Effects of basic fibroblast growth factor on the healing of partial-thickness donor sites. A prospective, randomized, double-blind trial. Wound Rep Regen 1994; 2: 113-21. (RCT)

5. Ma B, Cheng DS, Xia ZF, Ben DF, Lu W, Cao ZF, Wang Q, He J, Chai JK, Shen CA, Sun YH, Zhang GA, Hu XH. Randomized, multicenter, double-blind, and placebo-controlled trial using topical recombinant human acidic fibroblast growth factor for deep partial-thickness burns and skin graft donor sites. Wound Rep Regen 2007; 15: 795-9. (RCT)

6. Brown GL, Nanney LB, Griffen J, Cramer AB, Yancey JM, Curtsinger LJ III, Holtzin L, Schultz GS, Jurkiewicz MJ, Lynch JB. Enhancement of wound healing by topical treatment with epidermal growth factor. $N$ Engl J Med 1989; 321: 76-9. (RCT)

7. Gilpin DA, Barrow RE, Rutan RL, Broemeling L, Herndon DN. Recombinant human growth hormone accelerates wound healing in children with large cutaneous burns. Ann Surg 1999; 220: 19-24. (RCT)

8. Pelzer M, Hartmann B, Blome-Eberwein S, Raff T, Germann G. Effect of recombinant growth hormone on wound healing in severely burned patients. A placebo controlled, randomized double-blind phase II study. Chirurg 2000; 71: 1352-8. (RCT)

9. Herndon DN, Barrow RE, Kunkel KR, Broemeling L, Rutan RL. Effects of recombinant human growth hormone on donor-site healing in severely burned children. Ann Surg 1990; 212: 424-9. (RCT)

10. Losada F, Garcia-Luna PP, Gómez-Cía T, Garrido M, Pereira JL, Marín F, Astorga R. Effects of human recombinant growth hormone on donor-site healing in burned patients. World J Surg 2002; 26: 2-8. (RCT)

Guideline \#9.6: For deep burns that cannot undergo early excision and wound closure, topical antibacterial agents are indicated. For shallow wounds, donor sites, and meshed skin grafts, topical antibacterial agents have not proved necessary.

Level of evidence: II

Principle: Systemically administered antibiotics do not affect the bacteria-host defense equilibrium in wounds with necrotic tissue, decreased blood supply, or granulation tissue. Topical antimicrobials are more effective in these circumstances.

\section{Evidence:}

1. Robson MC, Edstrom LE, Krizek TJ, Groskin MG. The efficacy of systemic antibiotics in the treatment of granulating wounds. J Surg Res 1974; 16: 299-306. (EXP)

2. Hermans MHE. Results of an internet survey on the treatment of partial-thickness burns, full-thickness burns, and donor sites. J Burn Care Res 2007; 28: 835-47. (STAT)

3. Monafo WW, West MA. Current treatment recommendation for topical burn therapy. Drugs 1990; 40: 364-73. (LIT REV)

4. Heggers JP, Linares H, Edgar P, Villarreal C, Herndon D. Treatment of infection in burns. In: Herndon DN, editor. Total burn care. Philadelphia: W.B. Saunders Co., 1996: 98-135. (LIT REV) 
5. Tredget EE, Shankowsky HA, Groeneveld A, Burrell R. A matched-pair randomized study evaluating the efficacy of Acticoat silver-coated dressing for the treatment of burn wounds. J Burn Care Rehabil 1998; 19: 531-7. (RCT)

6. Innes ME, Umraw N, Fish JS, Gomez M, Cartotto $\mathrm{RC}$. The use of silver coated dressings on donor site wounds: a prospective, controlled matched pair study. Burns 2001; 27: 621-7. (RCT)

7. Silver GM, Robertson SW, Halerz MM, Conrad P, Supple KG, Gamelli RL. A silver-coated antimicrobial barrier dressing used postoperatively on meshed autografts: a dressing comparison study. J Burn Care Res 2007; 28: 715-9. (RCT)

8. Heinrich JJ, Brand DA, Cuono CB. The role of topical treatment as a determinant of infection in outpatient burns. J Burn Care Rehabil 1988; 9: 253-57. (CLIN S)

9. Rodgers GL, Fisher MC, Lo A, Cresswell A, Long SS. Study of antibiotic prophylaxis during burn wound debridement in children. J Burn Care Rehabil 1997; 18: 342-6. (RCT)

10. Durtschi MB, Orgain C, Counts GW, Heimbach DM. A prospective study of prophylactic penicillin in acutely burned hospitalized patients. J Trauma 1982; 22: 4-14. (RCT)

Guideline \#9.7: Advanced wound care dressings are more effective than simple impregnated gauze dressings at accelerating healing and decreasing pain in skin graft donor sites. The small differences in improvement must be balanced with the differences in cost and patient comfort.

Level of evidence: I

Principle: Donor sites heal by epithelialization and epithelialization is facilitated in a moist environment. Simple impregnated gauze dressings do not provide adequate moisture retention.

\section{Evidence:}

1. Pham C, Greenwood J, Cleland H, Woodruff P, Maddern G. Bioengineered skin substitutes for the management of burns: a systematic review. Burns 2007; 33: 946-51. (STAT)

2. Beldon P. Comparison of four different dressings on donor site wounds. Br J Nurs 2004; 13: S38-45. (RCT)

3. Barnea Y, Amir A, Leshem D, Zaretski A, Weiss J, Shafir R, Gur E. Clinical comparative study of aquacel and paraffin gauze dressing for split-skin donor site treatment. Ann Plast Surg 2004; 53: 132-6. (RCT)

4. Martini L, Reali UM, Borgognoni L, Brandani P, Andriessen A. Comparison of two dressings in the management of partial-thickness donor sites. $J$ Wound Care 1999; 8: 457-60. (RCT)

5. Rennekampff HO, Rabbels J, Reinhard V, Becker ST, Schaller HE. Comparing the Vancouver Scar Scale with the cutometer in the assessment of donor site wounds treated with various dressings in a randomized trial. J Burn Care Res 2006; 27: 345-51. (RCT)

6. Griswold JA, Cepica T, Rossi L, Wimmer JS, Merrifield $\mathrm{HH}$, Hester C, Sauter T, Baker CR. A comparison of Xeroform and Skin Temp dressings in the healing of skin graft donor sites. J Burn Care Rehabil 1995; 16: 136-40. (RCT)
7. Hickerson WL, Kealey GP, Smith DJ, Thomson PD. A prospective comparison of a new, synthetic donor site dressing versus an impregnated gauze dressing. $J$ Burn Care Rehabil 1994; 15: 359-63. (RCT)

8. Zapata-Sirvent R, Hansbrough JF, Carroll W, Johnson R, Wakimoto A. Comparison of Biobrane and Scarlet Red dressings for treatment of donor site wounds. Arch Surg 1985; 120: 743-5. (RCT)

9. Prasad JK, Feller I, Thomson PD. A prospective controlled trial of Biobrane versus scarlet red on skin graft donor areas. J Burn Care Rehabil 1987; 8: 384-6. (RCT)

10. Innes ME. Umraw N, Fish JS, Gomez M, Cartotto RC. The use of silver coated dressings on donor site wounds: a prospective, controlled matched pair study. Burns 2001; 27: 621-7. (RCT)

11. Verstraelen P. Comparison of calcium sodium alginate (KALTOSTAT) and porcine xenograft (E-Z DERM) in the healing of split-thickness skin graft donor sites. Burns 1992; 18: 145-8. (RCT)

12. Muhart M, McFalls S, Kirsner RS, Elgart GW, Kerdel F, Sabolinski ML, Hardin-Young J, Eaglstein WH. Behavior of tissue-engineered skin: a comparison of living skin equivalent, autograft, and occlusive dressing in human donor sites. Arch Dermatol 1999; 135: 913-8. (RCT)

\section{\# 10: GUIDELINES TO DECREASE THE IMPEDIMENT TO ACUTE WOUND HEALING CAUSED BY EXTERNAL AGENTS SUCH AS TOBACCO, DRUGS, ETC.}

Preamble: External agents that a patient is using, such as tobacco or drugs, can be detrimental to wound healing. When possible, these agents should be avoided or discontinued. If they cannot be discontinued, measures to counter or minimize their effects are required.

Guideline \#10.1: Cigarette smoking is associated with decreased healing and a higher incidence of wound complications. Patients should stop smoking at least 3-4 weeks before elective surgery and should not resume smoking in the postoperative period.

Level of evidence: I

Principle: Cigarette smoking has been shown to cause decreased synthesis of collagen types I and III, carbon monoxide formation, vasoconstriction with reduced blood flow, and decreased oxygen transport. This leads to an increased rate of infection, higher incidence of skin flap necrosis, increase in epidermolysis, a higher amputation rate, and a worse cosmetic result.

\section{Evidence:}

1. Freiman A, Bird G, Metelitsa AI, Barankin B, Lauzon GJ. Cutaneous effects of smoking. J Cutan Med Surg 2004; 8: 415-23. (LIT REV)

2. Theadom A, Cropley M. Effects of preoperative smoking cessation on the incidence and risk of intraoperative and postoperative complications in adult smokers: a systematic review. Tobacco Control 2006; 15: 352-8. (STAT)

3. Sorensen LT, Karismark T, Gottrup F. Abstinence from smoking reduces incisional wound infection: a 
randomized controlled trial. Ann Surg 2003; 238: 1-5. (RCT)

4. Padubidri AN, Yetman R, Browne E, Lucas A, Papay F, Larive B, Zins J, Vasconez LO. Complications of postmastectomy breast reconstructions in smokers, ex-smokers, and nonsmokers. Plast Reconst Surg 2001; 107: 342-9. (RETRO S)

5. Booi DI, Debats IB, Boeckx WD, van der Hulst RR. Risk factors and blood flow in the free transverse rectus abdominis (TRAM) flap: smoking and high flap weight impair the free TRAM flap microcirculation. Ann Plast Surg 2007; 59: 364-71. (CLIN S)

6. Sorensen LT, Horby J, Friis E, Pilsgaard B, Jørgensen T. Smoking as a risk factor for wound healing and infection in breast cancer surgery. Eur J Surg Oncol 2002; 28: 815-20. (CLIN S)

7. Kuri M, Nakagawa M, Tanaka H, Hasuo S, Kishi Y. Determination of the duration of preoperative smoking cessation to improve wound healing after head and neck surgery. Anesthesiology 2005; 102: 892-6. (RETRO S)

8. Manassa EH, Herti CH, Olbrisch RR. Wound healing problems in smokers and nonsmokers after 132 abdominoplasties. Plast Reconstr Surg 2003; 111: 2082-7. (RETRO S)

9. Nguyen TH, Gordon IL, Whalen D, Wilson SE. Transmetatarsal amputation: predictors of healing. Am Surg 2006; 72: 973-7. (CLIN S)

10. Jorgensen LN, Kallehave F, Christensen E, Siana JE, Gottrup F. Less collagen production in smokers. Surgery 1998; 123: 450-5. (CLIN S)

11. Knuutinen A, Kokkonen N, Risteli J, Vähäkangas K, Kallioinen M, Salo T, Sorsa T, Oikarinen A. Smoking affects collagen synthesis and extracellular matrix turnover in human skin. $B r J$ Dermatol 2002; 146: 588-94. (EXP)

12. Raitio A, Tuomas H, Kokkonen N, Salo T, Sorsa T, Hanemaaijer R, Oikarinen A. Levels of matrix metalloproteinase-2, -9 and -8 in the skin, serum and saliva of smokers and non-smokers. Arch Dermatol Res 2005; 197: 242-8. (EXP)

13. Reus WF 3rd, Colen LB, Straker DJ. Tobacco smoking and complications in elective microsurgery. Plast Reconstr Surg 1992; 89: 490-4. (RETRO S)

14. Siana JE, Rex S, Gottrup F. The effect of cigarette smoking on wound healing. Scand J Plast Reconstr Surg Hand Surg 1989; 23: 207-9. (CLIN S)

15. Lind J, Kramhoft M, Bedtker S. The influence of smoking on complications after primary amputations of the lower extremity. Clin Orthop Relat Res 1991; 267: 211-7. (RETRO S)

16. Rogliani M, Labardi L, Silvi E, Maggiulli F, Grimaldi M, Cervelli V. Smokers: risks and complications in abdominal dermolipectomy. Aesthet Plast Surg 2006; 30: 422-4. (RETRO S)

17. Lindström D, Wladis A, Linder S, Nåsell H, Adami J. Preoperative cessation of smoking seems to reduce the frequency of complications. Lakartidningen 2004; 101: 1920-2. (LIT REV)

Guideline \#10.2: Chronic corticosteroid usage should be minimized whenever possible before surgical procedures and until the acute wound is healed. When this is not pos- sible, various agents may be useful in decreasing the detrimental effects of corticosteroids on healing.

Level of evidence: II

Principle: The humoral and cellular inflammatory response is a fundamental part of the mechanism of acute wound healing. Corticosteroids can adversely affect several wound healing processes. Agents that can abrogate or ameliorate some of the effects of corticosteroids should benefit healing.

Evidence:

1. Hunt TK. Disorders of wound healing. World J Surg 1980; 4: 271-7. (LIT REV)

2. Stephens FO, Dunphy JE, Hunt TK. Effect of delayed administration of corticosteroids on wound contraction. Ann Surg 1971; 173: 214-8. (EXP)

3. Gupta A, Jain GK, Raghubir R. A time course study for the development for an immunocompromised wound model using hydrocortisone. J Pharmacol Toxicol Meth 1999; 4: 183-7. (EXP)

4. Hunt TK, Ehrlich HP, Garcia JA, Dunphy JE. Effect of vitamin A on reversing the inhibitory effect of cortisone on healing of open wounds in animals and man. Ann Surg 1969; 170: 633-41. (EXP)

5. Ehrlich HP, Tarver H, Hunt TK. Effects of vitamin A and glucocorticoids upon inflammation and collagen synthesis. Ann Surg 1973; 177: 222-7. (EXP)

6. Smith KP, Zardiakas LD, Didlake RH. Cortisone, vi$\operatorname{tamin} \mathrm{A}$, and wound healing: the importance of measuring wound surface area. J Surg Res 1986; 40: 120-5. (EXP)

7. Ehrlich HP, Hunt TK. Effects of cortisone and vitamin A on wound healing. Ann Surg 1968; 167: 324-8. (LIT REV)

8. Ehrlich HP, Hunt TK. The effects of corticosteroid and anabolic steroids on the tensile strength of healing wounds. Ann Surg 1969; 170: 203-6. (EXP)

9. Demling RH. Oxandrolone, an anabolic steroid, enhances the healing of a cutaneous wound in a rat. Wound Rep Regen 2000; 8: 97-102. (EXP)

10. Kim CS, Buchmiller TL, Fonkalsrud EW, Phillips JD. The effect of anabolic steroids on ameliorating the adverse effects of chronic corticosteroids on intestinal anastomotic healing in rabbits. Surg Gynecol Obstet 1993; 176: 73-9. (EXP)

11. Kelley SF, Felix AM, Ehrlich HP. The antagonism of glucocorticoid inhibition of wound healing in rats by growth hormone-releasing factor. Proc Soc Exp Biol Med 1990; 194: 320-6. (EXP)

12. Garrel DR, Gaudreau P, Zhang LM, Reeves I, Brazeau P. Chronic administration of growth hormone-releasing factor increases wound strength and collagen maturation in granulation tissue. J Surg Res 1991; 51: 297-302. (EXP)

13. Dinc S, Durmus E, Gulcelik MA, Kuru B, Ustun H, Renda N, Alagol H. Effects of beta-D-glucan on steroid-induced impairment of colonic anastomotic healing. Acta Chir Beig 2006; 106: 63-7. (EXP)

Guideline \#10.3: Zinc therapy improves healing in zincdeficient patients. Its benefit in patients without zinc deficiency has not been substantiated. 
Level of evidence: III

Principle: Zinc is an essential trace element and serves as a cofactor in numerous transcription factors and enzyme systems necessary for wound healing. However, exogenous zinc does not augment healing except in the presence of zinc deficiency.

\section{Evidence:}

1. Lansdown AB, Mirastschijski U, Stubbs N, Scanlon E, Agren MS. Zinc in wound healing: theoretical, experimental, and clinical aspects. Wound Rep Regen 2007; 15: 2-16. (LIT REV)

2. Agren MS. Studies on zinc in wound healing. Acta Derm Venereol 1990; 154 (Suppl.): 1-36. (EXP)

3. Faure H, Peyrin JC, Richard MJ, Favier A. Parental supplementation with zinc in surgical patients corrects postoperative serum-zinc drop. Biol Trace Elem Res 1991; 30: 27-45. (RCT)

4. Agren MS, Ostenfeld U, Kallehave F, Gong Y, Raffn $\mathrm{K}$, Crawford ME, Kiss K, Friis-Møller A, Gluud C, Jorgensen LN. A randomized, double-blind, placebocontrolled multicenter trial evaluating topical zinc oxide for acute open wounds following pilonidal disease excision. Wound Rep Regen 2006; 14: 526-35. (RCT)

5. Greenway SE, Filler LE, Greenway FL. Topical insulin in wound healing: a randomized, double-blind, placebocontrolled trial. J Wound Care 1999; 8: 526-8. (RCT)

Guideline \#10.4: There is insufficient evidence to recommend specific exogenous nutrients such as vitamins to improve acute wound healing in patients who are not deficient in those nutrients.

\section{Level of evidence: II}

Principle: Although specific actions of many individual nutrients could benefit acute wound healing, data are not available for definitive recommendations.

\section{Evidence:}

1. Silverstein RJ, Landsman AS. The effects of a moderate and high dose of vitamin $\mathrm{C}$ on wound healing in a controlled guinea pig model. J Foot Ankle Surg 1999; 38: 333-8. (EXP)

2. Vaxman F, Olender S, Lambert A, Nisand G, Grenier JF. Can the wound healing process be improved by vitamin supplementation? Experimental study on humans. Eur Surg Res 1996; 28: 306-14. (RCT)

3. Baumann LS, Spencer J. The effects of topical vitamin E on the cosmetic appearance of scars. Dermatol Surg 1999; 25: 311-5. (RCT)

4. Barbul A, Fishel RS, Shimazu S, Wasserkrug HL, Yoshimura NN, Tao RC, Efron G. Intravenous hyperalimentation with high arginine levels improves wound healing and immune function. J Surg Res 1985; 38: 328-34. (EXP)

5. Barbul A, Lazarou SA, Efron DT, Wasserkrug HL, Efron G. Arginine enhances wound healing and lymphocyte immune responses in humans. Surgery 1990; 108: 336-7. (RCT)

6. Kirk SJ, Hurson M, Regan MC, Holt DR, Wasserkrug HL, Barbul A. Arginine stimulates wound healing and immune function in elderly human beings. Surgery 1993; 114: 155-9. (RCT)
7. Shi HP, Most D, Efron DT, Witte MB, Barbul A. Supplemental L-arginine enhances wound healing in diabetic rats. Wound Rep Regen 2003; 11: 198-203. (EXP)

8. Shi HP, Wang SM, Zhang GX, Zhang YJ, Barbul A. Supplemental L-arginine enhances wound healing following trauma/hemorrhagic shock. Wound Rep Regen 2007; 15: 66-70. (EXP)

(The effects of hyperbaric oxygen on acute wound healing are discussed in Guideline \#1.3. The effects of anticoagulants on acute wound healing are discussed in Guideline \#3.1. The effects of chemotherapeutic drugs on acute wound healing are discussed in Guideline \#7.1.)

\section{\# 11: GUIDELINES TO DECREASE THE IMPEDIMENT TO ACUTE WOUND HEALING CAUSED BY EXCESSIVE SCAR FORMATION}

Preamble: In excessive healing or proliferative scarring, it is as if the equilibrium point between collagen deposition and collagen lysis is never reached. It is unclear why some wounds seem to continue in the repair processes without an apparent turnoff switch. Because of these unknowns, there is no universally accepted treatment regimen. In a recent metaanalysis of excessive scarring treatments, the mean amount of improvement to be expected was only $60 \%$.

Guideline \#11.1: Pressure garments or compression dressings are effective in decreasing scarring in burn injuries that require $>21$ days to heal.

\section{Level of evidence: I}

Principle: Excessive or hypertrophic scarring is rare in burn injuries that heal within 21 days. The exact mechanism by which pressure is effective is unknown.

\section{Evidence:}

1. Van den Kerckhove E, Stappaerts K, Fieuws S, Laperre J, Massage P, Flour M, Boeckx W. The assessment of erythema and thickness on burn related scars during pressure garment therapy as a preventive measure for hypertrophic scarring. Burns 2005; 31: 696-702. (RCT)

2. Klopp R, Niemer W, Frankel M, von der Weth A. Effect of four treatment variants on the functional and cosmetic state of mature scars. J Wound Care 2000; 9: 319-24. (RCT)

3. Chang P, Laubenthal KN, Lewis RW II, Rosenquist MD, Lindley-Smith P, Kealey GP. Prospective, randomized study of the efficacy of pressure garment therapy in patients with burns. J Burn Care Rehabil 1995; 16: 473-5. (RCT)

4. Huang TT, Blackwell SJ, Lewis SR. Ten years of experience in managing patients with burn contractures of axilla, elbow, wrist, and knee joints. Plast Reconstr Surg 1978; 61: 70-6. (RETRO S)

5. Van den Kerckhove E, Fieuws S, Massagé P, Hierner R, Boeckx W, Deleuze JP, Laperre J, Anthonissen M. Reproducibility of repeated measurements with the Kikuhime pressure sensor under pressure garments in burn scar treatment. Burns 2007; 33: 572-8. (CLIN S)

6. Cheng JC, Evans JH, Leung KS, Clark JA, Choy TT, Leung PC. Pressure therapy in the treatment of postburn hypertrophic scar-a critical look into its 
usefulness and fallacies by pressure monitoring. Burns Incl Therm Inj 1984; 10: 154-63. (CLIN S)

7. Deitch EA, Wheelahan TM, Rose MP, Clothier J, Cotter J. Hypertrophic burn scars: analysis of variables. $J$ Trauma 1983; 23: 895-8. (CLIN S)

8. Cubison TC, Pape SA, Parkhouse N. Evidence for the link between healing time and the development of hypertrophic scars (HTS) in paediatric burns due to scald injury. Burns 2006; 32: 992-9. (CLIN S)

Guideline \#11.2: Silicone sheeting is useful in prevention and treatment of proliferative scars.

Level of evidence: I

Principle: Although the exact mechanism by which silicone sheeting is effective is not agreed upon, it does decrease fibroblast activity and downregulates the fibrogenic isoforms of transforming growth factor- $\beta$ (TGF- $\beta$ ).

Evidence:

1. O'Brien L, Pandit A. Silicon gel sheeting for preventing and treating hypertrophic and keloid scars. Cochrane Database Syst Rev 2006; 1: CD003826. (STAT)

2. Ziegler UE. International clinical recommendations on scar management. Zentralbl Chir 2004; 129: 296-306. (STAT)

3. Leventhal D, Furr M, Reiter D. Treatment of keloids and hypertrophic scars: a meta-analysis and review of the literature. Arch Facial Plast Surg 2006; 8: 362-8. (STAT)

4. Li-Tsang CW, Lau JC, Choi J, Chan CC, Jianan L. A prospective randomized clinical trial to investigate the effect of silicone gel sheeting (Cica-Care) on post-traumatic hypertrophic scar among the Chinese population. Burns 2006; 32: 678-83. (RCT)

5. Gold MH, Foster TD, Adair MA, Burlison K, Lewis T. Prevention of hypertrophic scars and keloids by the prophylactic use of topical silicone gel sheets following a surgical procedure in an office setting. Dermatol Surg 2001; 27: 641-4. (RCT)

6. Ahn ST, Monafo WW, Mustoe TA. Topical silicone gel: a new treatment for hypertrophic scars. Surgery 1989; 106: 781-6. (RCT)

7. Ahn ST, Monafo WW, Mustoe TA. Topical silicone gel for the prevention and treatment of hypertrophic scar. Arch Surg 1991; 126: 499-504. (CLIN S)

8. Kuhn MA, Moffit MR, Smith PD, Lyle WG, Ko F, Meltzer DD, Robson MC. Silicone sheeting decreases fibroblast activity and downregulates TGF-B2 in hypertrophic scar model. Int J Surg Investig 2001; 2: 467-74. (EXP)

9. Berman B, Perez OA, Konda S, Kohut BE, Viera MH, Delgado S, Zell D, Li Q. A review of the biologic effects, clinical efficacy, and safety of silicone elastomer sheeting for hypertrophic and keloid scar treatment and management. Dermatol Surg 2007; 33: 1291-302. (LIT REV)

Guideline \#11.3: Intralesional corticosteroids, especially triamcinolone acetonide (Kenalog), can be a useful treatment of proliferative scars.

Level of evidence: I

Principle: Intralesional corticosteroid injections have been successful in treating hypertrophic scars and keloids, but the mechanism of action has not been defined despite a great deal of investigation.

\section{Evidence:}

1. Ziegler UE. International clinical recommendations on scar management. Zentralbl Chir 2004; 129: 296-306. (STAT)

2. Manuskiatti W, Fitzpatrick RE. Treatment response of keloidal and hypertrophic sternotomy scars: comparison among intralesional corticosteroid, 5-fluorouracil, and 585-nm flashlamp-pumped pulsed-dye laser treatments. Arch Dermatol 2002; 138: 1149-55. (RCT)

3. Kiil J. Keloids treated with topical injections of triamcinolone acetonide (Kenalog). Immediate and longterm results. Plast Reconstr Surg 1977; 11: 169-72. (RCT)

4. Asilian A, Darougheh A, Shariati F. New combination of triamcinolone, 5-fluorouracil, and pulsed-dye laser for treatment of keloid and hypertrophic scars. Dermatol Surg 2006; 32: 907-15. (RCT)

5. Layton AM, Yip J, Cunliffe WJ. A comparison of intralesional triamcinolone and cryosurgery in the treatment of acne keloids. Br J Dermatol 1994; 130: 498-501. (RCT)

6. Sclafani AP, Gordon L, Chadha M, Romo T III. Prevention of earlobe keloid recurrence with postoperative corticosteroid injections versus radiation therapy: a randomized, prospective study and review of the literature. Dermatol Surg 1996; 22: 569-74. (RCT)

7. Ketchum LD, Smith J, Robinson DW, Masters FW. Treatment of hypertrophic scars, keloid, and scar contracture by triamcinolone acetonide. Plast Reconstr Surg 1966; 38: 209-18. (CLIN S)

Guideline \#11.4: Agents that neutralize or abrogate the action of the fibrogenic isoforms of TGF- $\beta$ (TGF- $\beta 1$, TGF- $\beta 2$ ) may be useful in preventing or treating proliferative scars.

Level of evidence: II

Principle: It has been demonstrated that persistent overexpression or dysregulated activation of TGF- $\beta 1$ and TGF- $\beta 2$ can lead to fibrosis and scar formation, while TGF- $\beta 3$ tends to decrease fibrosis and scarring.

\section{Evidence:}

1. Shah M, Foreman DM, Ferguson MW. Neutralization of TGF-beta1 and TGF-beta2 or exogenous administration of TGF-beta3 to cutaneous rat wounds reduces scarring. J Cell Sci 1995; 108: 985-1002. (EXP)

2. Tredget EE, Wang R, Shen Q, Scott PG, Ghahary A. Transforming growth factor-beta mRNA and protein in hypertrophic scar tissues and fibroblasts: antagonism by IFN-alpha and IFN-gamma in vitro and in vivo. $J$ Interferon Cytokine Res 2000; 20: 143-51. (EXP)

3. Granstein RD, Rook A, Flotte TJ, Haas A, Gallo RL, Jaffe HS, Amento EP. A controlled trial of intralesional recombinant interferon-gamma in the treatment of keloidal scarring. Clinical and biologic findings. Arch Dermatol 1990; 126: 1295-302. (RCT)

4. Davison SP, Mess S, Kauffman LC, Al-Attar A. Ineffective treatment of keloids with interferon alpha-2b. Plast Reconstr Surg 2006; 117: 247-52. (RCT)

5. Tredget EE, Shankowsky HA, Pannu R, Nedelec B, Iwashina T, Ghahary A, Taerum TV, Scott PG. Transforming growth factor-beta in thermally injured patients with hypertrophic scars: effects of interferon alpha-2b. Plast Reconstr Surg 1998; 102: 1317-28. (CLIN S) 
6. Ferguson MW, O'Kane S. Scar-free healing: from embryonic mechanisms to adult therapeutic intervention. Philo Trans $R$ Soc Lond B Biol Sci 2004; 359: 839-50. (LIT REV)

7. Robson MC. Proliferative scarring. Surg Clin North Am 2003; 83: 557-69. (LIT REV)

8. Payne WG, Ko F, Anspaugh S, Wheeler CK, Wright TE, Robson MC. Down-regulating causes of fibrosis with tamoxifen: a possible cellular/molecular approach to treat rhinophyma. Ann Plast Surg 2006; 56: 301-5. (EXP)

Guideline \#11.5: Postoperative radiotherapy following excision of keloids may be useful in preventing recurrence. However, dosage regimens are not agreed upon, and there remains a theoretical argument against use of radiotherapy for benign conditions.

\section{Level of evidence: II}

Principle: Ionizing radiation can prevent recurrence of scar proliferation. Techniques vary widely, making results difficult to interpret.

\section{Evidence:}

1. Ziegler UE. International clinical recommendations on scar management. Zentralbl Chir 2004; 129: 296-306. (STAT)

2. van de Kar AL, Kreulen M, van Zuijien PP, Oldenburger $F$. The results of surgical excision and adjuvant irradiation for therapy-resistant keloids: a prospective clinical outcome study. Plast Reconstr Surg 2007; 119: 2248-54. (RCT)

3. Sclafani AP, Gordon L, Chadha M, Romo T III. Prevention of earlobe keloid recurrence with postoperative corticosteroid injections versus radiation therapy: a randomized, prospective study and review of the literature. Dermatol Surg 1996; 22: 569-74. (RCT)

4. Ogawa R, Miyashita T, Hyakusoku H, Akaishi S, Kuribayashi $\mathrm{S}$, Tateno A. Postoperative radiation protocol for keloids and hypertrophic scars: statistical analysis of 370 sites followed for over 18 months. Ann Plast Surg 2007; 59: 688-91. (CLIN S)

5. Akita S, Akino K, Yakabe A, Imaizumi T, Tanaka K, Anraku K, Yano H, Hirano A. Combined surgical excision and radiation therapy for keloid treatment. $J$ Craniofac Surg 2007; 18: 1164-9. (CLIN S)

6. Guix B, Henriquez I, Andrés A, Finestres F, Tello JI, Martínez A. Treatment of keloids by high-dose brachytherapy: a seven year study. Int J Radiat Oncol Biol Phys 2001; 50: 167-72. (CLIN S)

Guideline \#11.6: Laser therapy may be useful for the treatment of proliferative scars.

\section{Level of evidence: II}

Principle: Lasers used at nondestructive power levels have been demonstrated to cause inhibition of collagen production by keloid-derived fibroblasts. The almost endless variety of lasers and dosages prevent compilation of similar studies.

\section{Evidence:}

1. Abergel RP, Dwyer RM, Meeker CA, Lask G, Kelly AP, Uitto J. Laser treatment of keloids: a clinical trial and an in vitro study with Nd:Yag laser. Lasers Surg Med 1984; 4: 291-5. (CLIN S)

2. Manuskiatti W, Fitzpatrick RE. Treatment response of keloidal and hypertrophic sternotomy scars: comparison among intralesional corticosteroids, 5-fluorouracil, and 585-nm flashlamp-pumped pulsed-dye laser treatments. Arch Dermatol 2002; 138: 1149-55. (RCT)

3. Alster T. Laser scar revision: comparison study of 585$\mathrm{nm}$ pulsed-dye laser with and without intralesional corticosteroids. Dermatol Surg 2003; 29: 25-9. (RCT)

4. Jih MH, Friedman PM, Goldberg LH, Robles M, Glaich AS, Kimyai-Asadi A. The 1450-nm diode laser for facial inflammatory acne vulgaris: dose-response and 12-month follow-up study. $\mathrm{J}$ Am Acad Dermatol 2006; 55: 80-7. (RCT)

5. Weiss RA, Gold M, Bene N, Biron JA, Munavalli G, Weiss M, Beasley K. Prospective clinical evaluation of 1440-nm laser delivered by microarray for treatment of photoaging and scars. J Drugs Dermatol 2006; 8: 740-4. (CLIN S)

6. Hasegawa T, Matsukura T, Mizuno Y, Suga Y, Ogawa $\mathrm{H}$, Ikeda S. Clinical trial of a laser device called fractional photothermolysis system for acne scars. $J$ Dermatol 2006; 55: 80-7. (RCT)

Guideline \#11.7: Several treatments to minimize scarring or prevent recurrence of scars are based on biologic principles but, as yet, lack sufficient data for a recommendation. These include surgical techniques, lathrogens, Imiquimod, and vitamin E.

\section{Level of evidence: III}

Principle: Attacking the collagen deposition-collagen lysis equilibrium by mechanical, molecular, or pharmacologic means should lead to advances in treatment of excessive scarring.

\section{Evidence:}

1. Robson MC, Barnett RA, Leitch IOW, Hayward PG. Prevention and treatment of postburn scars and contracture. World J Surg 1992; 16: 87-96. (LIT REV)

2. Engrav LH, Gottlieb JR, Millard SP, Walkinshaw MD, Heimbach DM, Marvin JA. A comparison of intramarginal and extramarginal excision of hypertrophic burn scars. Plast Reconstr Surg 1988; 81: 40-5. (RETRO S)

3. Peacock EE. Pharmacologic control of surface scarring in human beings. Ann Surg 1981; 193: 592-7. (CLIN S)

4. Chuangsuwanich A, Gunjitisomram S. The efficacy of $5 \%$ Imiquimod cream in the prevention of recurrence of excised keloids. J Med Assoc Thai 2007; 90: 1363-7. (CLIN S)

5. Stashower ME. Successful treatment of earlobe keloids with Imiquimod after tangential shave excision. Dermatol Surg 2006; 32: 380-6. (CLIN S)

6. Bauman LS, Spencer J. The effects of topical vitamin E on the cosmetic appearance of scars. Dermatol Surg 1999; 25: 311-5. (RCT)

7. Ehrlich HP, Tarver H, Hunt TK. The inhibitory effects of vitamin $\mathrm{E}$ on collagen synthesis and wound repair. Ann Surg 1972; 175: 235-40. (EXP)

8. Lawrence WT. In search of the optimal treatment for keloids: report of a series and review of the literature. Ann Plast Surg 1991; 27: 164-78. (LIT REV) 